\title{
Evaluation of The Effects of Allium Jesdianum Bacterial Endophytes on Some Bacterial and Fungal Pathogens
}

\author{
Maryam Esmaeili ${ }^{1}(D)$, Azizollah Ebrahimi Kahrizsangi ${ }^{1}$, Somayeh Shahrokh Shahraki ${ }^{1,2^{*}}$ (D) , Azam Mokhtari ${ }^{1,2}$
}

1. Department of Pathobiology, Faculty of Veterinary Medicine, Shahrekord University, Shahrekord, Iran

2. Research Institute of Zoonotic Diseases, Shahrekord University, Shahrekord, Iran

$\underline{10.30699 / i j m m .15 .3 .281}$

\section{ABSTRACT}

Background and Aim: The endophytes are the fungi or bacteria that live within a plant in a symbiotic relationship. This study aimed to investigate the effect of isolated bacterial endophytes from Allium jesdianum on some bacterial pathogens such as Staphylococcus aureus, Escherichia coli as well as pathogenic fungi, including Trichophyton mentagrophytes and Candida albicans.

Materials and Methods: Various parts of $A$. jesdianum including leaves, stems, onions and flowers were randomly collected, cleaned from any contamination and then cultured in a suitable culture medium. The endophyte colonies were purified using chloroform to analyze the anti-pathogenic properties of the structural agents of the bacterial endophyte. To evaluate the anti-pathogenicity of endophyte metabolites, the broth media of the endophyte bacteria was centrifuged and the supernatants were filtered through sterilization. Antibiogram test was performed by disk diffusion method (Kirby Bauer) and the sensitivity was compared. Data were statistically analyzed by t-test and ANOVA.

Results: Eleven bacterial endophytes were obtained from various sections of $A$. jesdianum. The endophyte bacterium has an improved antimicrobial effect on $T$. mentagrophytes. Unlike $E$. coli, secretory metabolites of endophytic bacteria had an antimicrobial effect on $S$.aureus and C. albicans.

Conclusion: It can be concluded that the bacterial endophytes of $A$. jesdianum can be considered to be potential and beneficial agents against human pathogens. $A$. jesdianum with anti-pathogenic activity could be a source to produce important anti-pathogenic compounds from an agricultural and pharmaceutical point of view.

Keywords: Allium jesdianum, Anti-pathogenic activity, Endophyte, Medicinal plants, Microbial Sensitivity Tests

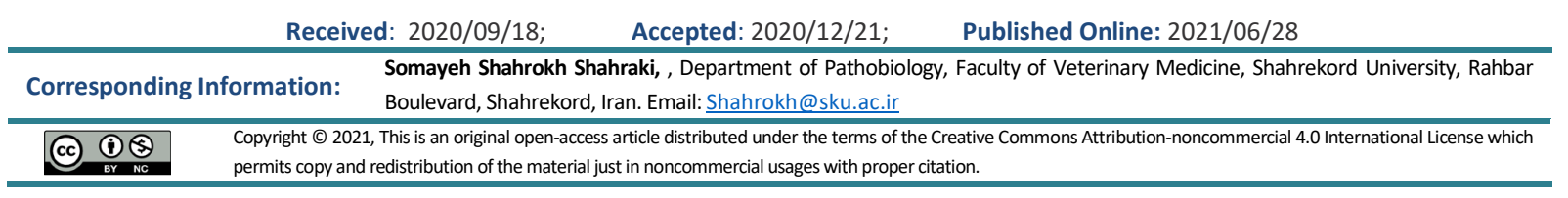

Use your device to scan and read the article online

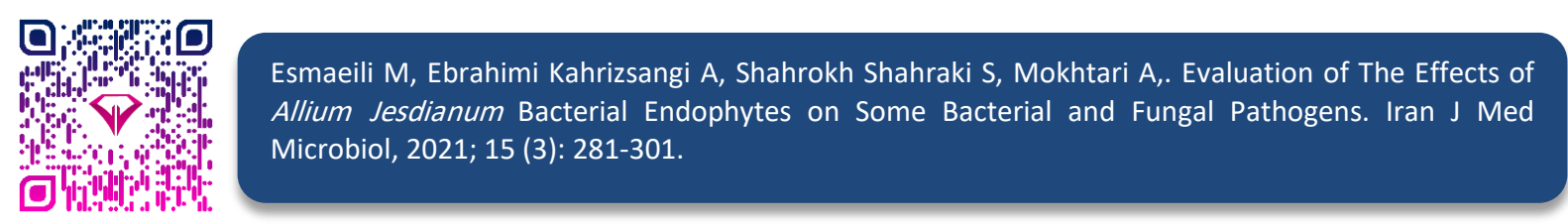

Download citation: BibTeX | RIS | EndNote | Medlars | ProCite | Reference Manager | RefWorks
Send citation to:
8 Mendeley
(2) Zotero
Bi RefWorks

\section{Introduction}

Herbal medicines are a group of herbs that contain a number of important compounds for medicine and pharmacy (1). Effective herbal remedies have attracted global attention because of their easy access and low side effects (2). Endophytes have been found to reside in the host tissues without apparent damage or signs of disease promoting plant growth and health (Symbiotic effect). Also, they provide a high resistance to a variety of diseases. Endophytes are powerful producer of secondary metabolites (3). Antimicrobial metabolites extracted from endophytes belong to variety structural classifications, including peptides, alkaloids, phenols, steroids, flavonoids, terpenoids, etc. (4). Common endophytes including a variety of bacteria (actinomycetes) and fungi are generally isolated from plants (5). These microorganisms have 
antifungal and anti-bacterial properties and prevent pathogens from entering the plant (6). New antibiotics (antimycotics), and anticancer compounds are just few examples of endophytes isolates (7).

Due to the increasing of the antibiotic resistance of pathogenic microbes, some of antibiotics can be substituted by endophytes and they may provide the alternative sources of bioactive compounds and probiotics for treatment of some bacterial and fungal diseases (8).

Escherichia coli is the leading cause of death worldwide with a wide range of diseases. Each year, it causes widespread infant mortality due to diarrhea and septicemia (9). E. coli strains are generally resistant to a number of medications (10).

Various Staphylococcus aureus isolates have different responses in terms of antibiotic sensitivity or resistance. Scientific reports have suggested that methicillin-resistant strains of $S$. aureus (MRSA) indicating changes in the epidemiology of this bacterium.

The ability of some Allium species has been shown to reduce risk factors such as elevated serum cholesterol, elevated LDL, increased platelets, hypertension, and other factors by in vitro studies $(14,15)$. Allium jesdianum belongs to the Alliaceae family which grows in the west and southwest of Iran and is traditionally effective in treating and alleviating rheumatic and gastrointestinal pain, renal stone excretion as well as colds and abdominal pain. It has analgesic and pain relieving properties $(16,17)$.

In this study, the bacterial endophytes were firstly isolated from $A$. jesdianum and then their antifungal and anti-bacterial properties against some pathogenic bacteria and fungi were investigated.

\section{Materials and Methods}

\section{Isolation of Endophytic Bacteria}

Fresh samples of $A$. jesdianum (various parts of the herb including stem, leaf, onion and flower) were collected randomly from Chaharmahal and Bakhtiari province, Iran, in the spring 2019. In this clinical trial study, a minimum of 30 and a maximum of 50 fresh samples of $A$. jesdianum were used to isolate a maximum of 10 bacterial endophytes to evaluate their antibacterial and antifungal properties. Samples of $A$. jesdianum were transferred to the microbiology laboratory at Shahrekord University, Chaharmahal and Bakhtiari, Iran. The genus and species of this plant were confirmed taxonomically by the Department of Botany.

The plant was cleaned, sterilized and dried. The stems, leaves, onions and flowers of $A$. jesdianum were separately placed in $70 \%$ ethanol for 2 minutes. They were then immersed in $5.3 \%$ sodium hypo- chlorite solution and $75 \%$ ethanol for 5 minutes and 30 seconds, respectively (18). Subsequently, the ingredients of the plant were washed with sterile distilled water and then dried. The final distilled water was then cultured on a nutrient agar as a control. For the isolation of endophytic bacteria, stems, leaves, flowers and onions were cut by a sterile scalpel and transferred into agar media containing yeast extract (Merck, 64271, Germany) or YEA (Yeast Extract Agar: Yeast Extract 5g/L, Glucose10g/L, Agar 16g/L) and the pepton agar medium (Pepton Agar: Pepton Water $15 \mathrm{~g}$ (Difco, 1807-17-4)/L, Agar 16g/L (Quelab, 420223). All culture media and the control plates were directly incubated at $35^{\circ} \mathrm{C}$ for $4-7$ day. After the incubation period, the endophytes were developed in the plates and labeled at random for better identification. Each colony was examined macroscopically on an individual basis (19). The morphology of the purified colony of the endophytic bacteria was recorded in terms of shape, color and size. Bacterial identification were done by catalase and oxidase tests, gram staining and biochemical assays $(20,21)$.

\section{Bacterial and Fungal Strains}

Respectively, S. aureus (ATCC: 25923) and E. coli (ATCC: 25922) as standard strains were collected from Shahrekord University of Medical Sciences, Iran. Biochemical and morphological identification were carried out to confirm the prepared strains (21). C. albicans and $T$. mentagrophytes, as fungi, were obtained from Department of Mycology, University of Tehran, Iran and were re-cultured in the sabouraud dextrose agar medium (Merck, Germany).

\section{Investigation of Antibacterial and Antifungal Properties of Agents Within the Endophytic Bacteria Through the Drip Method by Chloroform (DMC)}

Three to four entirely similar colonies of endophyte bacteria were separately cultured in a Pepton water medium (Difco, 1807-17-4) and incubated at $37^{\circ} \mathrm{C}$ for 18 to 24 hours. A total of $50 \mu \mathrm{L}$ of the prepared suspension of each endophyte was placed on Pepton Agar and Yeast Extract Agar medium (YEA, Merck-, 64271 , Germany) and incubated $\left(37^{\circ} \mathrm{C}\right.$ for $18-24$ hours). In the next step, the surface of the endophytic colonies were coated by chloroform for 20 to 30 minutes until chloroform completely evaporated (19).

Three to four completely identical colonies of each pathogens (S. aureus ATCC 25923, E. coli ATCC 25922 and $C$. albicans) were cultured separately in a Tryptic Soy Broth (TSB) medium and incubated for 24 hours at $37^{\circ} \mathrm{C}$. After the incubation period, $200 \mu \mathrm{L}$ was collected from the TSB medium (at a concentration of $0.5 \mathrm{McFarland}$ ) and transferred into tubes containing $10 \mathrm{~mL}$ of semisolid $\mathrm{BHI}$ culture medium (Himedia, 400086) in 37 to $40^{\circ} \mathrm{C}$. 
The contents of each tube were added to the surface of the YEA and PA medium containing endophytic bacterial colonies, so that the surface of the plate was completely covered with $\mathrm{BHI}$ medium and incubated at $37^{\circ} \mathrm{C}$ for 18 to 24 hours.

A total of 1-2 pure cultured colonies of $T$. mentagrophytes were also removed by a needle and cultured $1 \mathrm{~cm}$ away from the endophyte bacterial colony at four corners of the plate. Following this period, the diameter of the growth inhibition zone of the pathogens formed around each endophytic colony was measured and recorded in millimeters. Each endophytic isolate was tested separately. Also, before performing the aforementioned steps, to find the antibacterial and antifungal properties of the endophytes, the antibiogram of pathogens was examined and confirmed in the standard tables. The experiments were repeated in triplicate and the standard deviation of the mean (SD) as well as standard error of the mean (SEM) was calculated and documented (19).

Investigation of Antibacterial and Antifungal Properties of Endophytic Bacteria by Secretory Metabolite Test (SMeT)

Three to four colonies of each endophytic bacterium were cultured separately in a LB broth (Luria Bertani Broth, Merck, 110285, Germany) and incubated at $37^{\circ} \mathrm{C}$ for $18-24$ hours.

The standard pathogens including S. aureus, E.coli, and $C$. albicans were cultured in LB medium and incubated. A total of $200 \mu \mathrm{L}$ of LB medium, at the appropriate concentration of 0.5 McFarland, was added to $15 \mathrm{~mL}$ of YEA medium, mixed and poured into sterile plates. Without wasting time and before the solidification of the culture medium, the sterile aluminum cylinders $(0.5 \mathrm{~cm}$ in diameter and $1 \mathrm{~cm}$ in height) were inserted into the plates with appropriate spacing. The YEA culture medium was prepared and autoclaved and poured in the plates. Before solidification of the culture medium, the sterile aluminum cylinders were inserted into the plates. A total of 1-2 pure colonies of $T$. mentagrophytes were removed by a straight needle and cultured in 4 corners of the plate, containing YEA medium. A total of $1 \mathrm{~mL}$ of LB broth (Merck, 110285, Germany) containing cultured endophyte bacteria at the appropriate concentration (standard 0.5 McFarland) was transferred to a sterile microtube. The microtube contents were centrifuged (Sigma, serial no. 103286) at 10,000 rpm for 15 minutes. After filtration of the centrifugal supernatant, $100 \mu \mathrm{L}$ was removed and carefully poured into each cylinder. Sterile water was also considered as a control group. The plates were incubated at $37^{\circ} \mathrm{C}$ for $24 \mathrm{~h}$. These steps were performed separately for each endophytic strain as well as pathogens. After incubation, the created diameter of the pathogens growthless zone ( $S$. aureus ATCC: 25923, E.coli ATCC: 25922 and C. albicans) around each cylinder was measured and recorded in millimeters. Growth in T. mentagrophytes was also evaluated and compared to the controls. The experiments were repeated and the standard deviation of the mean (SD) as well as standard error of the mean (SEM) were calculated and documented (22).

\section{Statistical Analysis}

Data was statistically analyzed by SPSS 22 (SPSS Inc., Chicago, IL., USA). The Antimicrobial effect of $A$. jesdianum endophytes on the pathogens (S. aureus, $E$. coli \& C. albicans) was calculated in both methods. Also, the inhibitory effect of all endophyte samples in DMC and SMeT were reported by T-test and ANOVA statistical tests.

\section{Results}

\section{Isolated Bacterial Endophytes}

A total of 11 bacterial endophytes were collected from various parts of the herb including stem, leaf, onion and flower. The results have demonstrated the different effects of the bacterial endophytes isolated from the $A$. jesdianum on some examined pathogens. Out of 11 endophytes isolated from this plant, 4 bacterial endophytes were gram-positive and 7 gramnegative. Amongst these endophytes, 6 were Cocci, 3 Bacilli and 2 Cocco bacillus. The endophytes with both antimicrobial and antifungal properties belonged to both gram-positive and gram-negative groups with different forms. Most of the bacterial endophytes obtained from the plant were cocci and bacilli. All 11 endophytes isolated from $A$. jesdianum were grown in different culture media such as Yeast Extract Agar, Peptone Agar, Blood Agar, TSB, LB (Luria Bertani Broth) and also Manitol salt Agar. Colonies of bacterial endophytes in the Peptone Agar medium showed the better growth. Furthermore, the colonies in the YEA medium were weaker than that of the PA medium.

The secretory metabolites of the isolated bacterial endophyte from all parts of the plant (stem, leaf, onion and flower) showed remarkable and favorable antibacterial and antifungal effect on the examined pathogens (Table 1-2). In general secretory metabolites of $A$. jesdianum's bacterial endophytes demonstrated the better inhibitory growth effects than endophytes.

Antibacterial Effect of $A$. jesdianum Against $S$. aureus (ATCC: 25923)

In this study, through the drip method by chloroform (DMC), endophytes of $A$. jesdianum showed a favorable effect on S. aureus (ATCC: 25923) (Figure 1). 


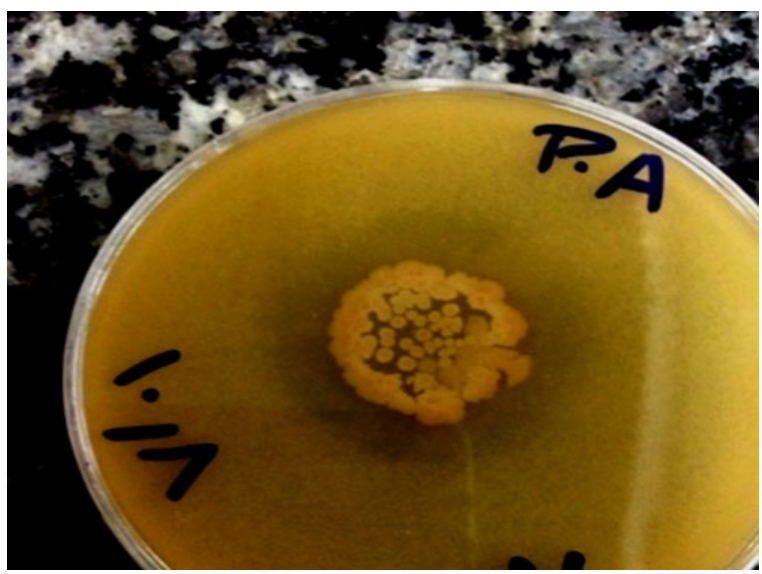

Figure 1. Growth inhibiting effect of $A$. jesdianum endophyte called "M" on S. aureus (ATCC:25923) by chloroform drip method.

In general the best antibacterial effect of endophytes was on S. aureus (ATCC: 25923). However, the secretory metabolites of most isolated bacterial endophytes showed favorable inhibitory effects on $S$. aureus (ATCC: 25923) (Figure 2).

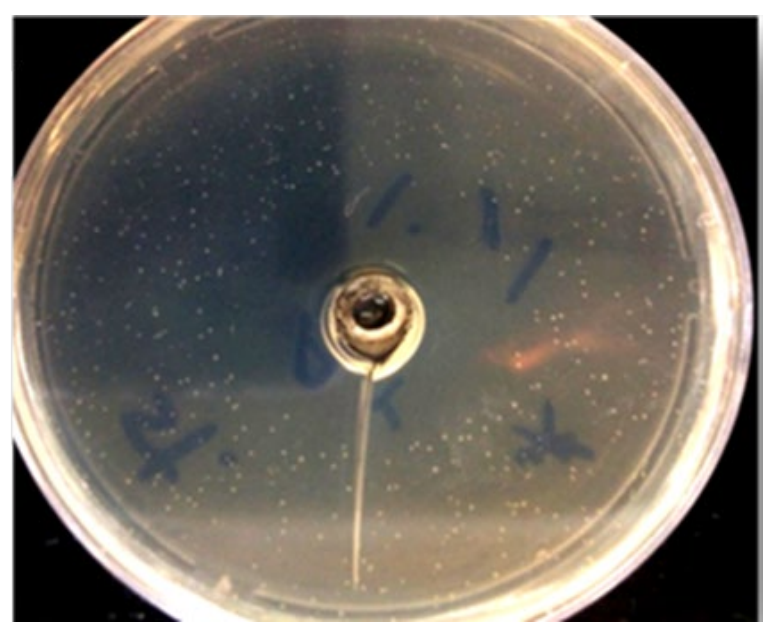

Figure 2. Antibacterial effect of $A$. jesdianum endophyte " $\mathrm{S}$ " metabolite on S. aureus

\section{Antibacterial Effect of $A$. jesdianum Against $E$. coli (ATCC: 25922)}

None of the 11 bacterial endophytes isolated from $A$. jesdianum were effective in the two methods, per chloroform drip, and evaluating the effect of secreting metabolites on E. coli (ATCC: 25922) (Table 1).

A very weak growth inhibitor zone against E.coli was created by the secretory metabolites of 2 isolated endophytic bacteria (C1 and C2) (Table 2).

\section{Antifungal Effect of $A$. jesdianum Against $C$. albicans}

Using the chloroform drip method, only the endophytes named " $\mathrm{K}$ ", " $\mathrm{H}$ " and " $\mathrm{Z}$ ", which have been isolated from the flowers and bulbs of $A$. jesdianum, created a very weak growth inhibition against $C$. albicans. In other bacterial endophytes, no growth inhibitory zone was observed against C. albicans, however three endophytes created a very small zone (Table 1).

The secretory metabolites of the isolated endophytic bacteria from $A$. jesdianum showed relatively positive inhibitory effects on $C$. albicans and only one bacterial endophyte "W" showed no growthless halo (Table 2).

Table 1. Mean diameter (SD) of growth inhibition zone of bacteria (S. aureus \& E. coli) and fungus (C. albicans) in millimeters based on bacterial endophytic structure factors in $A$. jesdianum by bacterial colony drip method using chloroform

\begin{tabular}{|c|c|c|c|c|c|}
\hline Endophytes & Morphology & Plant section & $\begin{array}{l}\text { S. aureus } \\
\text { (SD) }\end{array}$ & $\begin{array}{c}\text { E. coli } \\
\text { (SD) }\end{array}$ & $\begin{array}{l}\text { C. albicans } \\
\text { (SD) }\end{array}$ \\
\hline $\mathbf{K}$ & Bacilli $\mathrm{G}^{-}$ & Onion & $34.5(1.5)^{*}$ & $0(0)$ & $4(2)$ \\
\hline M & Cocci $\mathrm{G}^{-}$ & Leaf & $36.5(3.5)$ & $0(0)$ & $0(0)$ \\
\hline $\mathbf{F}$ & Cocco Bacillus $\mathrm{G}^{+}$ & Leaf & $18.5(3.5)$ & $0(0)$ & $0(0)$ \\
\hline $\mathrm{C}_{1}$ & Cocci $\mathrm{G}^{+}$ & Leaf & $5(1)$ & $0(0)$ & $0(0)$ \\
\hline $\mathrm{C}_{2}$ & Cocci $\mathrm{G}^{+}$ & Leaf & $1.5(1.5)$ & $0(0)$ & $0(0)$ \\
\hline $\mathbf{S}$ & Cocci $\mathrm{G}^{+}$ & Leaf & $0(0)$ & $0(0)$ & $0(0)$ \\
\hline $\mathbf{w}$ & Cocco Bacillus G- & Leaf & $0(0)$ & $0(0)$ & $0(0)$ \\
\hline $\mathbf{B}_{1}$ & Cocci $\mathrm{G}^{+}$ & Stem & $0(0)$ & $0(0)$ & $0(0)$ \\
\hline $\mathbf{B}_{2}$ & Cocci $\mathrm{G}^{+}$ & Stem & $12.5(2.5)$ & $0(0)$ & $0(0)$ \\
\hline $\mathbf{H}$ & Bacilli G- & Onion & $15(1)$ & $0(0)$ & $2(2)$ \\
\hline $\mathbf{Z}$ & Bacilli $\mathrm{G}^{-}$ & Flower & $2(2)$ & $0(0)$ & $6(1)$ \\
\hline
\end{tabular}

* The number in parentheses indicates the standard error of mean (SEM). 
Table 2. Mean diameter (SD) of growth inhibition zone of bacteria (S. aureus \& E.coli) and fungus (C. albicans) influenced by endophytic bacterial secretory metabolites of $A$. jesdianum

\begin{tabular}{|c|c|c|c|c|c|}
\hline Endophytes & Morphology & Plant section & S. aureus (SD) & E. coli (SD) & C. albicans (SD) \\
\hline K & Bacilli $\mathrm{G}^{-}$ & Onion & $27(3)^{*}$ & $0(0)$ & $10.5(2.5)$ \\
\hline M & Cocci $\mathrm{G}^{-}$ & Leaf & $21.5(3.5)$ & $0(0)$ & $8.5(1.5)$ \\
\hline $\mathbf{F}$ & Cocco Bacillus G+ & Leaf & $0(0)$ & $0(0)$ & $13(2)$ \\
\hline $\mathrm{C}_{1}$ & Cocci $\mathrm{G}^{+}$ & Leaf & $18.5(5.5)$ & $2(0)$ & $9(1)$ \\
\hline $\mathrm{C}_{2}$ & Cocci $\mathrm{G}^{+}$ & Leaf & $21(1)$ & $3(0)$ & $12.5(1.5)$ \\
\hline $\mathbf{S}$ & Cocci $\mathrm{G}^{+}$ & Leaf & $27(3)$ & $0(0)$ & $11.5(1.5)$ \\
\hline $\mathbf{W}$ & Cocco Bacillus G - & Leaf & $14.5(0.5)$ & $0(0)$ & $0(0)$ \\
\hline $\mathbf{B}_{1}$ & Cocci $\mathrm{G}^{+}$ & Stem & $26.5(3.5)$ & $0(0)$ & $11(1)$ \\
\hline $\mathbf{B}_{\mathbf{2}}$ & Cocci $\mathrm{G}^{+}$ & Stem & $0(0)$ & $0(0)$ & $14(1)$ \\
\hline $\mathbf{H}$ & Bacilli G - & Onion & $24(2)$ & $0(0)$ & $12.5(1.5)$ \\
\hline $\mathbf{Z}$ & Bacilli G - & Flower & $35.5(4.5)$ & $0(0)$ & $15(2)$ \\
\hline
\end{tabular}

* The number in parentheses indicates the standard error of mean (SEM).

\section{Antifungal Effect of $A$. jesdianum Against $T$.} mentagrophytes

Using the chloroform drip method, out of 11 isolated bacterial endophytes, only 4 endophytes named "S", " $Z$ ", "W", and " $K$ ", which were isolated from the flowers, onions, and leaves of $A$. jesdianum, showed antifungal activity against the $T$. mentagrophytes. The secretory metabolites of the 11 bacterial endophytes isolated from $A$. jesdianum showed no effect on the $T$. mentagrophytes growth (Table 3).

\section{Antibiogram Test}

The results of antibiogram test was using the disc diffusion method are presented in the diameter of the growth inhibition zone (Table 4).

\section{Statistical Analysis}

There was a significance difference between all endophytes' antimicrobial effect in using drip method by chloroform (DMC) compared to secretory metabolite test (SMeT) in term of inhibitory effect on S. aureus.

Table 3. Antifungal properties of endophyte bacteria against Trichophyton mentagrophytes growth based on chloroform drip method and endophytic bacterial secretory metabolites of Allium jesdianum

\begin{tabular}{|c|c|c|c|c|}
\hline Endophytes & Morphology & Plant section & $\begin{array}{l}\text { Effects of endophytic } \\
\text { secretory metabolites }\end{array}$ & $\begin{array}{c}\text { Effect of endophytic } \\
\text { structural factors }\end{array}$ \\
\hline $\mathbf{B}_{1}$ & Cocci $\mathrm{G}^{+}$ & Stem & Negative & Negative \\
\hline $\mathbf{B}_{2}$ & Cocci $\mathrm{G}^{+}$ & Stem & Negative & Negative \\
\hline $\mathrm{C}_{1}$ & Cocci $\mathrm{G}^{+}$ & Leaf & Negative & Negative \\
\hline $\mathrm{C}_{2}$ & Cocci $\mathrm{G}^{+}$ & Leaf & Negative & Negative \\
\hline $\mathbf{S}$ & Cocci $\mathrm{G}^{+}$ & Leaf & Negative & Positive \\
\hline w & Cocco Bacillus G - & Leaf & Negative & Positive \\
\hline $\mathbf{M}$ & Cocci G - & Leaf & Negative & Negative \\
\hline $\mathbf{F}$ & Cocco Bacillus G ${ }^{+}$ & Leaf & Negative & Negative \\
\hline H & Bacilli G - & Onion & Negative & Negative \\
\hline K & Bacilli G- & Onion & Negative & Positive \\
\hline Z & Bacilli G - & Flower & Negative & Positive \\
\hline
\end{tabular}


Table 4. Diameter of growthless aura created in antibiogram test against S. aureus \& E. coli.

\begin{tabular}{|ccc|}
\hline Antibiotics & $\begin{array}{c}\text { S. aureus } \\
\text { (ATCC: 25923) }\end{array}$ & E. coli (ATCC:25922) \\
\hline Doxycycline & 13 & 24 \\
\hline Chloramphenicol & 14 & 20 \\
\hline Cefteriaxone & 0 & - \\
\hline Nalidixic acid & 0 & 19 \\
\hline Furazolidone & 19 & 0 \\
\hline Ampiciline & 0 & - \\
\hline Lyncomycin & 20 & -18 \\
\hline
\end{tabular}

Except for endophytes "S", a significance difference was reported between all endophytes using the drip method by chloroform compared to secretory metabolite test in term of inhibitory effect on $C$. albicans.
Amongst all endophytes, "C1" and "C2" showed a significant difference inhibitory effect on $E$. coli in both methods. The obtained data from the effect of various endophytes on growing of three pathogens in both methods are presented in Table 5 .

Table 5. Comparison between the inhibitory effects of Allium jesdianum endophytes on growing of three pathogens in both methods.

\begin{tabular}{|c|c|c|c|c|c|c|c|c|c|}
\hline $\begin{array}{l}\text { Bacterial } \\
\text { Endophyte }\end{array}$ & $\begin{array}{l}\text { S. aureus } \\
\text { DMC }\end{array}$ & $\begin{array}{l}\text { S. aureus } \\
\text { SMeT }\end{array}$ & P-value & $\begin{array}{l}\text { E. coli } \\
\text { DMC }\end{array}$ & $\begin{array}{l}\text { E. coli } \\
\text { SMeT }\end{array}$ & P-value & $\begin{array}{c}\text { C. } \\
\text { albicans } \\
\text { DMC }\end{array}$ & $\begin{array}{l}\text { C. albicans } \\
\text { SMeT }\end{array}$ & P-value \\
\hline B1 & $0.00 \pm 0.00$ & $26.00 \pm 3.60$ & 0.006 & $0.00 \pm 0.00$ & $0.00 \pm 0.00$ & 1 & $0.00 \pm 0.00$ & $12.00 \pm 2.00$ & $<0.001$ \\
\hline B2 & $12.33 \pm 2.51$ & $0.00 \pm 0.00$ & 0.001 & $0.00 \pm 0.00$ & $0.00 \pm 0.00$ & 1 & $0.00 \pm 0.00$ & $12.66 \pm 2.08$ & 0.009 \\
\hline $\mathbf{F}$ & $18.00 \pm 3.6$ & $0.00 \pm 0.00$ & 0.013 & $0.00 \pm 0.00$ & $0.00 \pm 0.00$ & 1 & $0.00 \pm 0.00$ & $13.33 \pm 2.09$ & 0.008 \\
\hline M & $36.00 \pm 3.67$ & $21.33 \pm 3.51$ & 0.007 & $0.00 \pm 0.00$ & $0.00 \pm 0.00$ & 1 & $0.00 \pm 0.00$ & $8.66 \pm 1.52$ & 0.010 \\
\hline H & $15.00 \pm 1.00$ & $23.66 \pm 2.51$ & 0.005 & $0.00 \pm 0.00$ & $0.00 \pm 0.00$ & 1 & $2.07 \pm 1.67$ & $11.66 \pm 1.08$ & 0.004 \\
\hline C1 & $4.66 \pm 1.54$ & $18.33 \pm 5.50$ & 0.014 & $0.00 \pm 0.00$ & $1.00 \pm 0.93$ & $<0.001$ & $0.00 \pm 0.00$ & $8.33 \pm 1.50$ & 0.001 \\
\hline C2 & $1.33 \pm 1.52$ & $19.66 \pm 2.50$ & $<0.001$ & $0.00 \pm 0.00$ & $1.57 \pm 1.37$ & $<0.001$ & $0.00 \pm 0.00$ & $13.33 \pm 2.05$ & 0.008 \\
\hline K & $34.00 \pm 1.73$ & $27.00 \pm 3.00$ & 0.025 & $0.00 \pm 0.00$ & $0.00 \pm 0.00$ & 1 & $3.66 \pm 2.08$ & $10.66 \pm 2.51$ & 0.021 \\
\hline $\mathbf{S}$ & $0.00 \pm 0.00$ & $26.666 \pm 3.05$ & $<0.001$ & $0.00 \pm 0.00$ & $0.00 \pm 0.00$ & 1 & $0.00 \pm 0.00$ & $11.66 \pm 1.49$ & $<0.001$ \\
\hline $\mathbf{w}$ & $0.00 \pm 0.00$ & $15.33 \pm 1.52$ & $<0.001$ & $0.00 \pm 0.00$ & $0.00 \pm 0.00$ & 1 & $0.00 \pm 0.00$ & $0.00 \pm 0.00$ & 1 \\
\hline $\mathbf{Z}$ & $2.00 \pm 1.82$ & $34.66 \pm 4.72$ & $<0.001$ & $0.00 \pm 0.00$ & $0.00 \pm 0.00$ & 1 & $6.00 \pm 1.41$ & $15.00 \pm 2.00$ & 0.010 \\
\hline
\end{tabular}

DMC: Drip method by chloroform

SMeT: Secretory metabolite test

\section{Intra-group Analysis}

A significance difference between the "B1", "S" and "W" with other endophytes in terms of inhibitory effects on $S$. aureus was reported in DMC method $(P<0.05)$. There was also, significant difference amongst other endophytes including $M, K, F, H, B 2, C 1$, $Z$, and $C 2$ in terms of inhibitory effects on $S$. aureus by DMC method (Figure 3).

S. aureus significantly showed a difference growing pattern using SMeT $(P<0.05)$. Specifically, a significant difference between the "B2" and " $F$ " endophytes with other endophytes in terms of inhibitory effects on $S$. aureus was observed $(P<0.05)$.

The inhibitory effect of all endophytes in DMC and SMeT on each of the $S$. aureus was showed in Figure 3.
The obtained data from inhibitory effect of various endophytes on $C$. albicans by both groups are expressed in Figure 4. A significant difference between the "W" endophyte with other endophytes was observed in terms of inhibitory effect on $C$. albicans in DMC method $(P<0.05)$. While, the "W", "C1", "M", "S", "B1", "C2" and " $F$ " endophytes showed significant difference respected to inhibitory effect compared to " $\mathrm{H}$ ", "Z" and "K" endophytes on C. albicans by SMeT $(P<0.05)$ (Figure 4).

There was no significant difference amongst various endophytes in terms of inhibitory effect on $E$. coli using SMeT and DMC. 


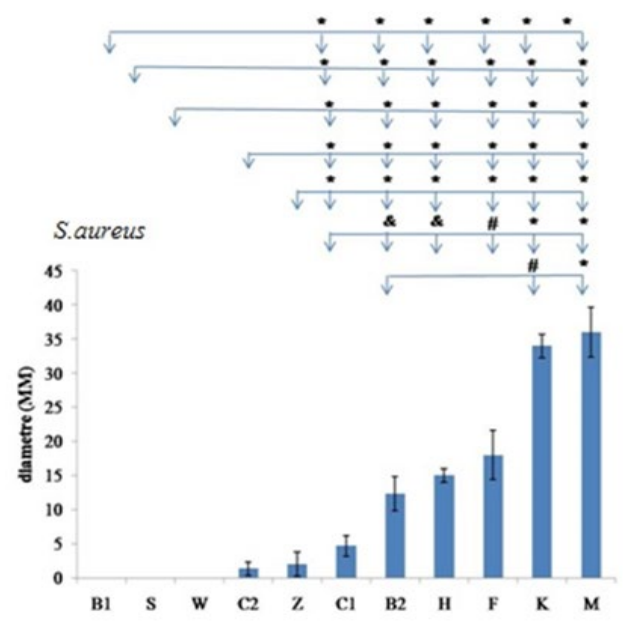

DMC

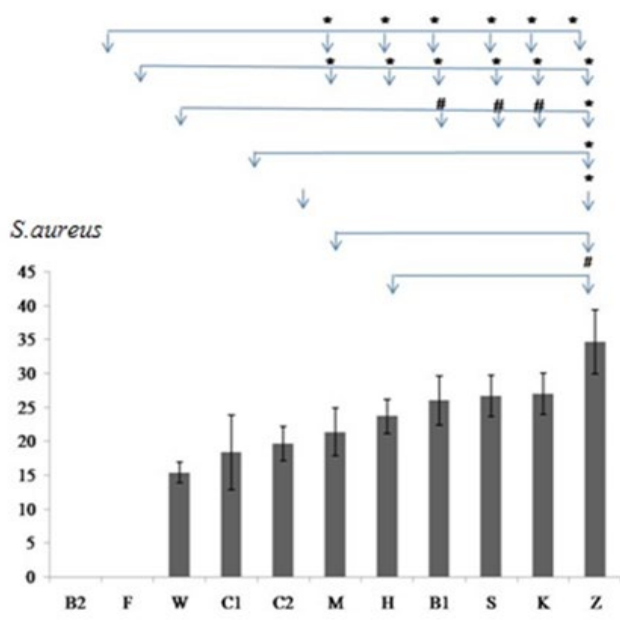

SMeT

Figure 3. The inhibitory effect of $A$. jesdianum endophytes on $S$. aureus in both methods, DMC: drip method by chloroform SMeT: secretory metabolite test; * \#, \& characters show the significant difference, $P<0.001, P<0.01$, and $P<0.05$, respectively.

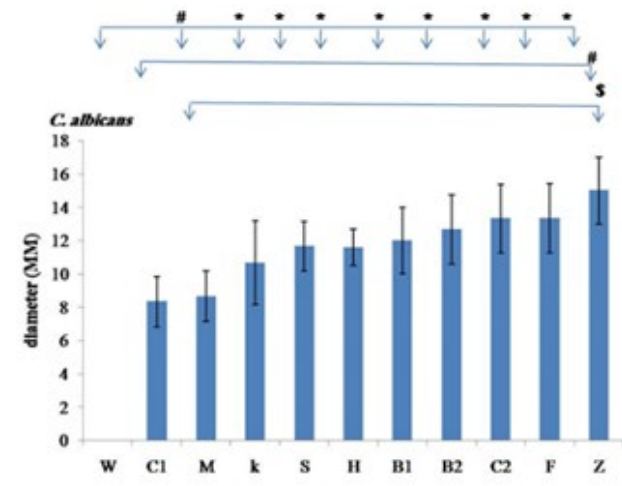

DMC
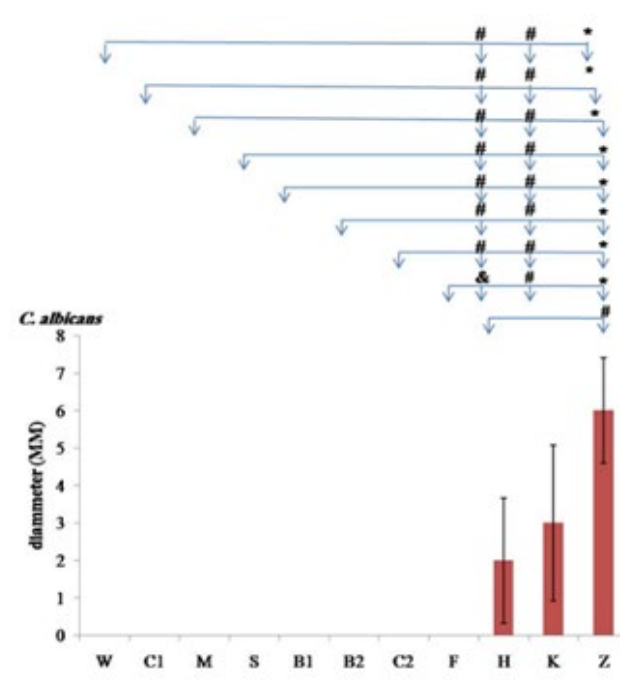

SMeT

Figure 4. The inhibitory effect of $A$. jesdianum endophytes on C. ablicans in both methods, DMC: drip method by chloroform SMeT: secretory metabolite test, $*, \#, \&$ characters show the significant difference $P<0.001, P<0.01$, and $P<0.05$, respectively.

\section{Discussion}

Since this study was designed to investigate the effect of Allium jesdianum's bacterial endophytes on the certain fungal and bacterial pathogens, the main findings of the present study was the potency and effectiveness of the bacterial endophytes in inhibiting of the aforementioned human pathogens' growth. Eleven bacterial endophytes were obtained from various sections of $A$. Jesdianum. In general, endophytes have an improved inhibitory effect on $T$. mentagrophytes. Secretory metabolites of endophytic bacteria had a positive effect on $S$. aureus and C.albicans.

Endophytic bacteria have been widely obtained from a variety of plants that sustain one or more endophytes in 300,000 species on the earth (23). Until now, several studies have been attempted to identify and isolate microbial endophytes from a variety of medicinal plants in which the antifungal and antibacterial properties of endophytes have been demonstrated (24).

The method proposed by the present study for the superficial sterilization of the plant is an effective method for the isolation of endophytes. The process of removing epiphytic microorganisms and rhizospheres from the soil, which are brought to the laboratory with plant samples, has been used in several ways over the last few years. Washing the samples by alcohol and sodium hypochlorite is one of 
the main and constant steps $(25,26)$. To ensure sterilization of the samples surface, the last distilled water solution (used for washing) was cultured and the presence of bacteria was detected. The lack of bacterial growth indicates that the surface sterilization steps were performed correctly. It can be ensured that the bacteria isolated from the plant samples were endophytes. In addition to the high growth of $A$. jesdianum endophytic bacteria, this paper provides a simple and powerful method of surface sterilization of plant tissues for better separation of endophytes in the plant.

The anti-diabetic and anti-tumor properties of endophytes have been recently demonstrated (27). Sebola et al. (2019) showed the antibacterial activity of extract of bacterial endophytes (28). The existence of endophytics in various parts of plants has also been reported previously $(29,30)$. Vu et al., (2019) have isolated 111 endophytic actinomycetes from roots, stems and leaves of the Cinnamomum cassia Presl, with different antimicrobial activity (30).

In the present study, the endophytes were mainly isolated from the leaves compared to other parts. " $M$ " endophyte $(36 \pm 3.67)$ in the chloroform drip method and " $Z$ " endophyte (34.66 \pm 4.7$)$ in endophytic secretory metabolite test showed significant effects on inhibition of $S$. aureus.

There was a significant difference amongst all endophytes against $S$. aureus indicated by the mean diameter of the growth inhibition zone using both methods $(P<0.05)$.

All 11 endophytes isolated from $A$. jesdianum were grown in Manitol salt Agar, after 24-48 hours, which indicates they have a high tolerance to sodium chloride salt. Microorganisms' growth inhibitory effect of the plant extracts is caused by some of the phytochemical compounds such as tannins, saponins, terpenoids, alkaloids, flavonoids, phenols and steroids, etc. that is extracted by chloroform (31). Allium species contain vital compounds such as carbohydrates, flavonoids and saponins. These species possess important biological and pharmacological activities such as antifungal, antibacterial, anti-tumor, antiinflammatory, anti-thrombotic and hypocholesterolemia properties $(32,33)$. The antimicrobial and antifungal properties of endophytes compounds are possible to be extracted by chloroform $(34,35)$. The antioxidant properties of Allium are related to the flavonoids and phenolic compounds (36).

Amiri (2007) demonstrated that ethanolic extract has stronger antimicrobial effects than those of the essential oil and other extracts of $A$. jesdianum. The antimicrobial properties of oil and ethanolic extracts are related to their sulfide and terpenoid compounds (37). Studies demonstrated that Allium bakhtiaricum chloroform fraction has a suppressive effect on breast cancer (38). The antioxidative properties of allium species possibly function with organosulfur compounds (39). El-Gendy et al. (2018) have carried out studies on the bioactive metabolites from various marine endophysical Streptomyces species against MRSA (40).

The antifungal activity and immunomodulatory effect of $A$. jesdianum Boiss extracts against $C$. albicans has been shown (41). According to statistical analyses, "K", "Z" and " $\mathrm{H}$ " endophytes have significant inhibitory effects on $C$. albicans's growth by both methods $(P<0.05)$. In the present study, the secretory metabolites of endophytic bacteria isolated from $A$. jesdianum demonstrated relatively favorable inhibitory effects on C. albicans.

Of the eleven isolated endophytes, only one endophyte, which was named "W", showed no effect on the growth of $C$. albicans. Furthermore, endophytic bacteria had the better antifungal properties against C. albicans compared to $T$. mentagrophytes. The secretory metabolites of all the isolated bacterial endophytes from $A$. jesdianum showed no effect on the growth of $T$. mentagrophytes, however the bacteria's body had more favorable inhibitory effect on this fungus compared to secretory metabolites. Secondary compounds such as pigments, plant growth regulator factors and mycotoxins, are among the metabolites produced by these endophytes (42).

The secretory metabolites of $A$. jesdianum may contain antibacterial, antifungal and other pharmaceutical compounds. In general, the secretory metabolites of bacterial endophytes of $A$. jesdianum showed the stronger inhibitory effect than those of bacteria's body against $C$. albicans.

In disc diffusion antibiogram (Kirby Bauer) tests against $S$. aureus (ATCC: 25923), the largest diameter of the no-growth zone was $20 \mathrm{~mm}$ which belonged to the Lincomycin antibiotic. Whereas, in the metabolite study, the mean diameter (SD) of the growthless zone created was $35.5 \mathrm{~mm}$ which belonged to an endophytic bacterium called " $Z$ ", in the DMC, the standard mean diameters of the growth inhibition zone created by bacterial endophytes known as " $\mathrm{M}$ " and " $\mathrm{K}$ " were $36.5 \mathrm{~mm}$ and $34.5 \mathrm{~mm}$, respectively. Because of the widespread and increasing bacterial and fungal infections resistance to antibiotics, isolation and identification of bacterial endophytes can be a good approach to overcome the resistance of human pathogens against antibiotics (43). The obtained data from the present study indicate that the resulting bacterial endophytes have a better inhibitory effect on gram-positive bacteria. The achievement of this important objective is the use of these endophytic bacteria in the production of medication with less side 
effects and the better effect against Gram-positive bacteria and pathogenic fungi.

Jiang et al. (2018) investigated the 101 actinobacteria as endophytes in which 31 strains showed positive inhibitory effect on at least one bacterium and 21 strains showed inhibitory activity against at least one "ESKAPE" (Enterococcus faecium, Staphylococcus aureus, Klebsiella pneumoniae, Acinetobacter baumanii, Pseudomonas aeruginosa, and Enterobacter species) resistant pathogens (44). Numerous bioactive compounds derived from endophytes are used as a major resource in various pharmaceutical formulations (45). Endophytic bacteria play an important role in both medicine and pharmacy. The bacterial endophytes of $A$. jesdianum and their properties can be used to produce antimicrobial agents, particularly for pathogens that are resistant to common antibiotics. In addition, they can be applied in agriculture and food industries.

\section{Acknowledgment}

Acknowledgements: This work was supported by Shahrekord University (grant numbers: 96GRD1M1801 and 96PRM2M50457).

\section{Funding}

The financial resources of this research were provided by Ms. Habibi Nava

\section{Conflict of Interest}

The author declared no conflict of interest. 


$$
\begin{aligned}
& \text { مجله ميكروبشناسى يزشكى ايران }
\end{aligned}
$$

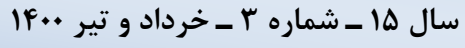

$$
\begin{aligned}
& \text { Journal homepage: www.ijmm.ir }
\end{aligned}
$$

\title{
بلى تأثير اندوفيتهاى باكتريايى Allium jesdianum برخى از پاتوزنهاى باكتريايى و قارجى
}

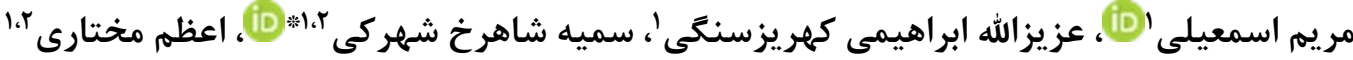

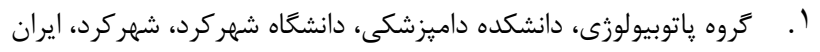

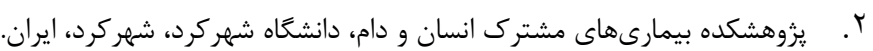

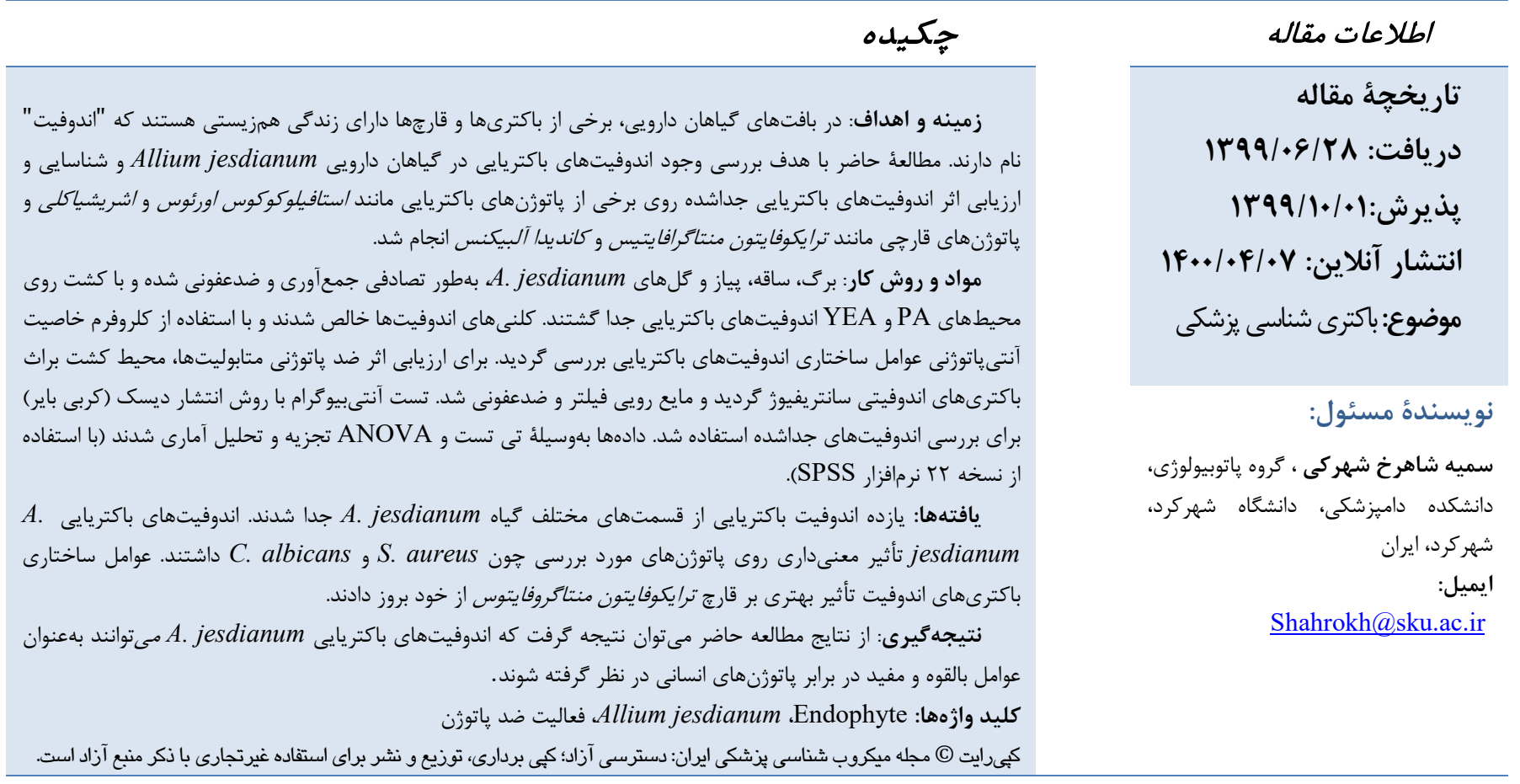

مقدمه

كه باطور كلى از كَياهان جدا مىشوند (ه). اين ميكرواركانيسمها داراى خواص ضد قارجى و ضد باكتريايى هستند و همجنين آندان مىتوانند از ورود عوامل بيمارىزا به كياه جلوكيرى كنند (9).

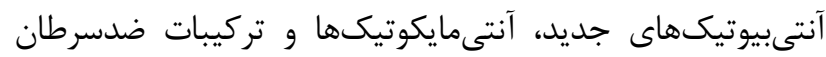

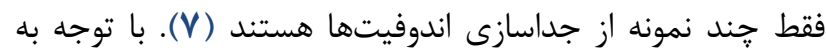
افزايش مقاومت آنتىبيوتيكى ميكروبهاى بيمارىزا، اندوفيتها مىتوانند جايكزين مناسبى براى برخى از آنتىبيوتيكها باشند و همجنين ممكن است منابعى جايكزين براى تركيبات بيواكتيو و

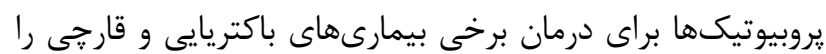

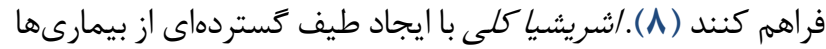
علت اصلى مرگ و مير در سراسر جهان است. اين باكترى هر ساله
كياهان دارويى، گروهى از گَاهان هستند كه داراى تركيبات مهمى براى صنعت داروسازى مىباشند (1). كياهان دارويى مؤثر به دليل دسترسى آسان و عوارض جانبى كم، توجه جهانى را به خود داري

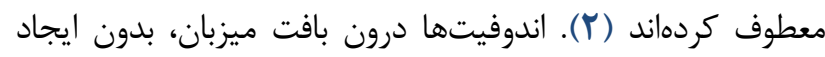

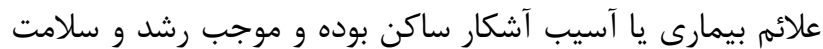

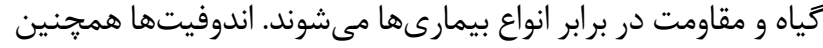
توليدكنندة قدرتمند متابوليتهاى ثانويه محسوب مىشوند (ץ). متابوليتهاى ترشحى ضد ميكروبى استخراجشده از اندوفيتها به آهنائ طبقدبندىهاى مختلف ساختارى از جمله يِيتيدها، آلكالوئيدها، فنولها، استروئيدها، فلاونوئيدها، ترينوئيدها و غيره تعلق دارند (F). اندوفيتها شامل انواع باكترىها (اكتينومايستها) و قارجها هستند 
دقيقه قرار داده شدند. سيس در محلول هييوكلريت سديم س/به درصد

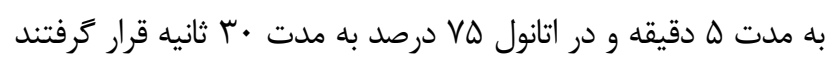

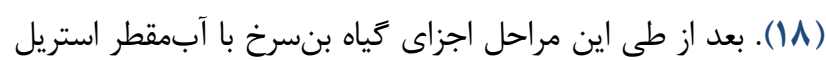

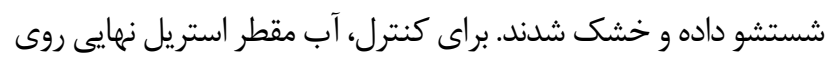

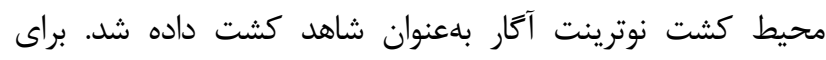

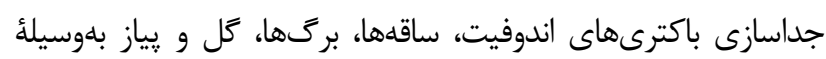

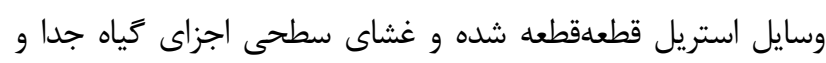

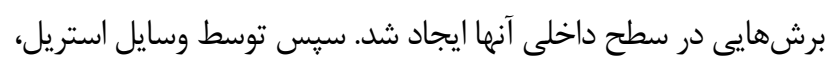

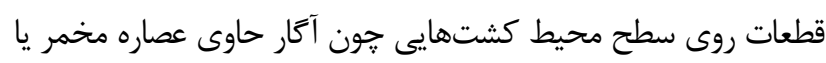
YEA (Yeast Extract Agar : Yeast Extract 5g/l, Gloucose 10g/l و نيز محيط كشت يِّتون (Merck,64271,Germany), Agar 16g/l) (Pepton Agar: Pepton water 15g (Difco, 1807-17-4)/L, آكار مديط Agar 16g/L (Quelab, 420223)

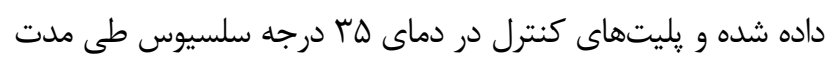

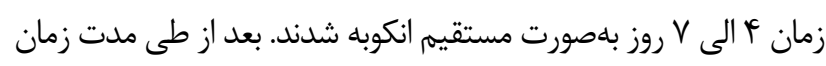

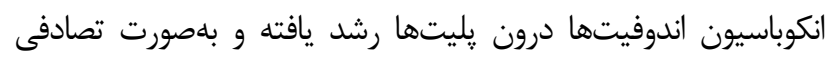
نامخذارى شدند. هر كلنى به تفكيك محل جداسازى (ساقه، برى، بياز

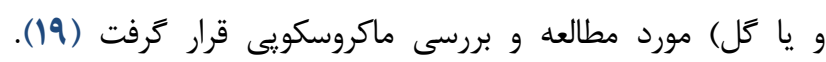

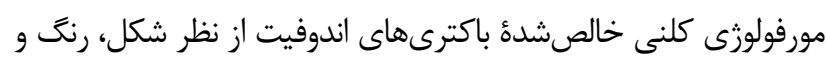

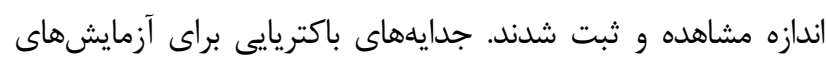

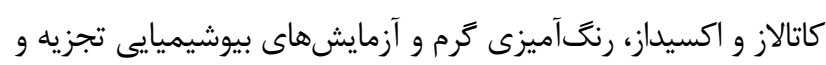

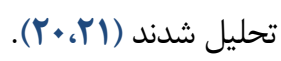

\section{سويه هاى باكتريايى و قارجى}

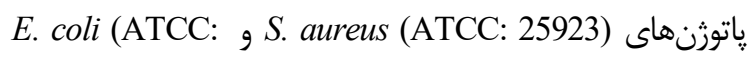

(25922) بهعنوان سويه استاندارد از دانشخاه علوم يزشكى شهركرد (ATCC:

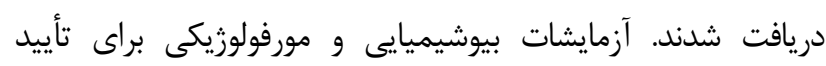

$$
\text { سويههاى تهيهشده انجام شد (Iالب). }
$$

قارجهاى C. albicans و T. mentagrophytes از آزمايشكاه قارج

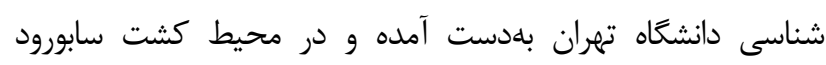
دكستروز آكار (Merck,Germany) كشت مجدد شدند.

\section{بر رسى خواص ضد باكتريايى و ضد قارجى عوامل موجود

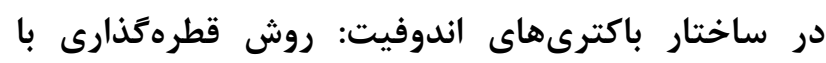 كلروفرم (DMC)}

سه تا جهار كلنى كاملاً مشابه از باكترىهاى اندوفيت بهطور

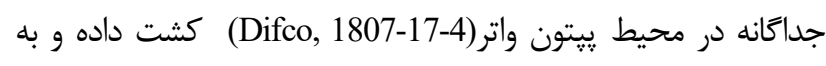

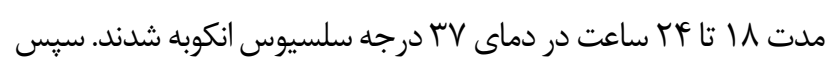

باعث مرى گسترده نوزادان به دليل اسهال و سيتىسمى مىشود (9). سويههاى E. coli بهطور كلى در برابر تعدادى از داروها مقاوم

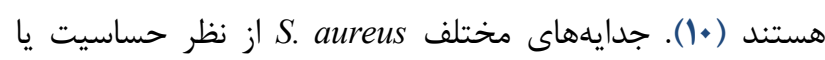

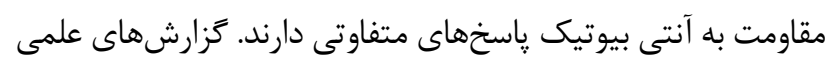

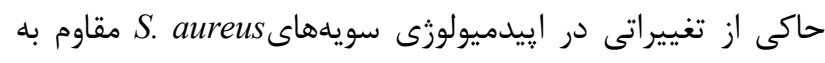

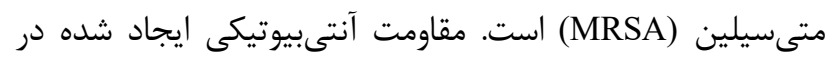

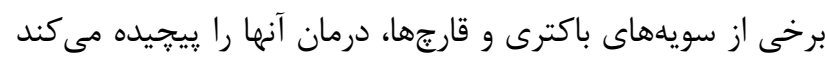

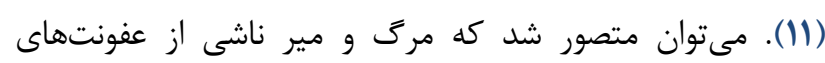

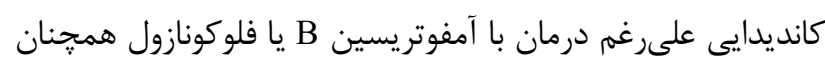

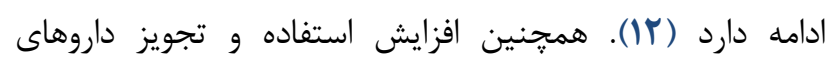

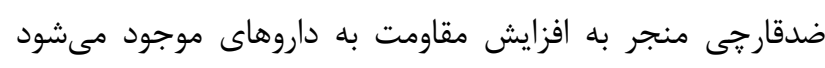
(r) صور). مطالعات in vitro كونهاى Allium مىتوانند باعث كاهش ريسك فاكتورهايى مانند

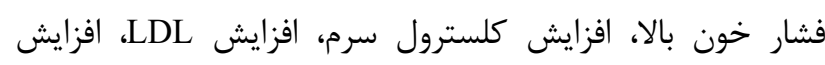

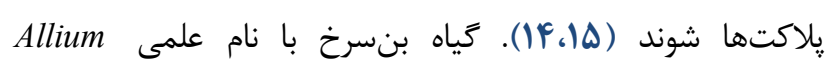

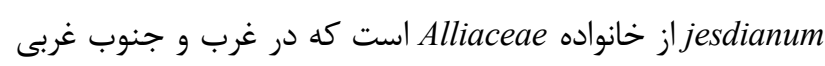
ايران رشد كرده و بهصورت سنتى در درمان و تسكين دراده دردهاى

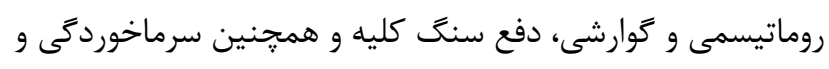

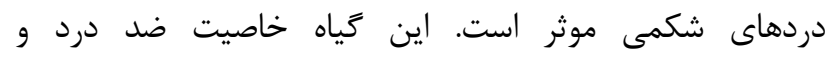

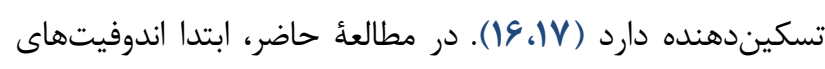

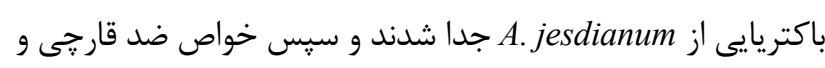
ضد باكتريايى آنها در برابر برخى باكترىها و قارجهاي جدائ بيمارىز بررسى شد.

مواد و روشها

\section{جداسازى باكترىهاى اندوفيت كَياه بنسرخ}

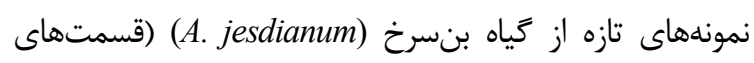

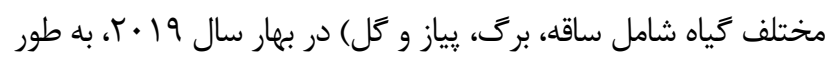

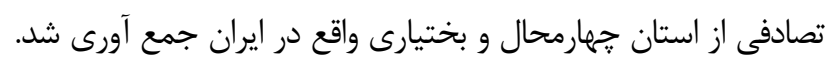

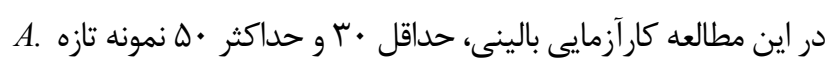

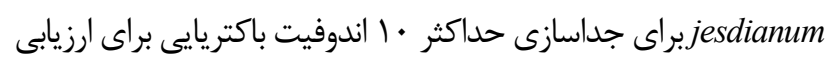

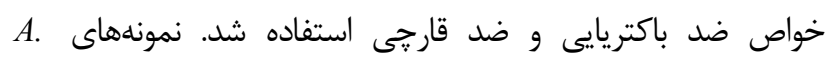
jesdianum

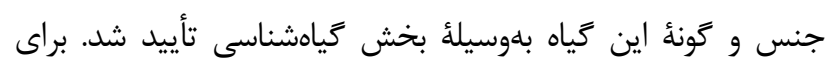

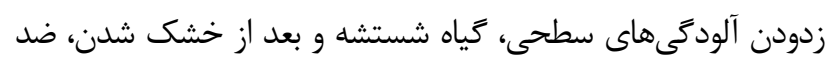

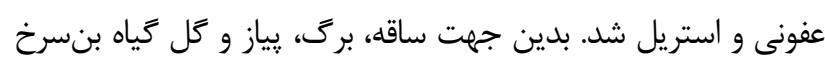

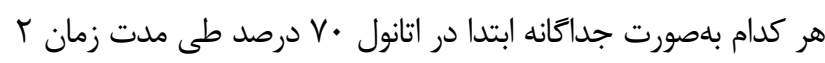


ه/ • مك فارلند، را برداشته و باصورت جداكانه به ها ميلىليتر محيط YEA

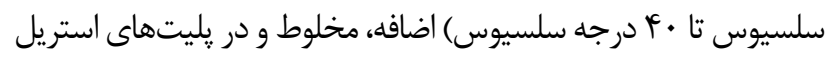

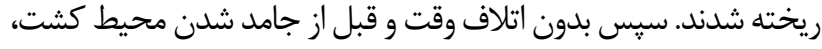

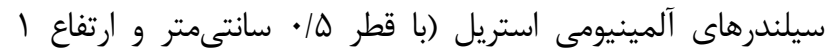

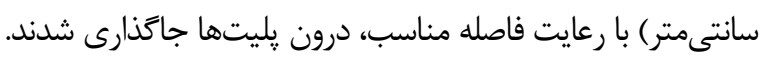
در جاى ديكر محيط كشت YEA تهيه و اتوكلاو شده و در يليتها ريخته شد. قبل از جامد شدن محيط كشت، سيلندرهاى

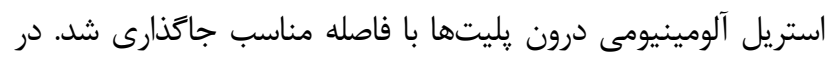
مجموع ا-T كلنى خالص T.mentagrophytes با يك آنس سوزنى

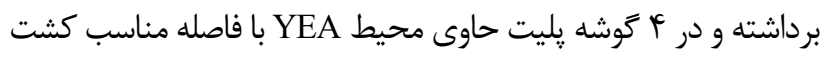

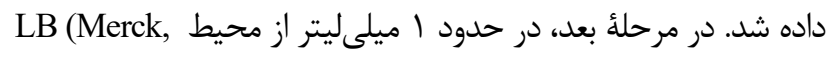
110285, Germany) غلظت مناسب (استاندارد ه/ • مك فارلند) به يك ميكروتيوب استريل

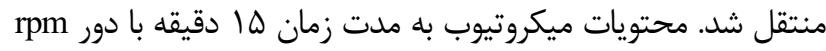
1....

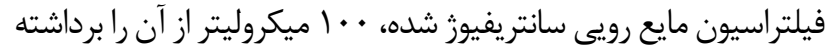

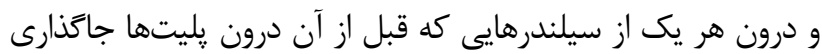

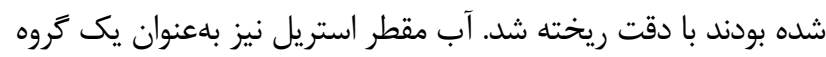

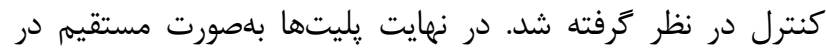

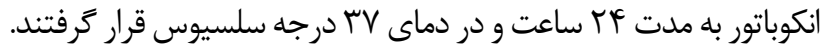

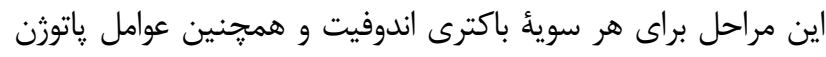

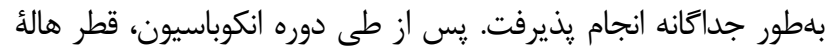

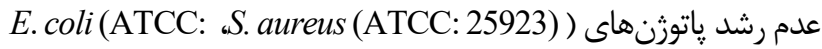
كه در اطراف هر سيلندر ايجاد شد اندازميرى (C. albicans و 25922) و بر حسب ميلىمتر ثبت شدند. ميزان رشد در T. mentagropytes نيز بررسى و با گروه شاهد مورد مقايسه قرار كرفت. آزمايشات تكرار و و

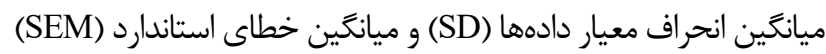

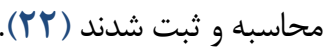

\section{تحليل و آناليز آمارى دادهها}

SPSS Inc., Chicago, Ill., ) SPSS داده ها با نسخه بr نرمافزار تجزيه و تحليل شدند. دادههاى بهدستآمده از تأثير (USA

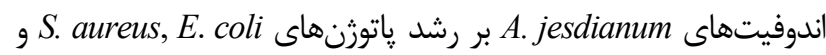
C.albicans

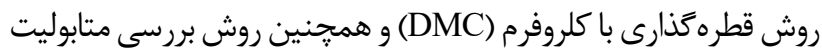

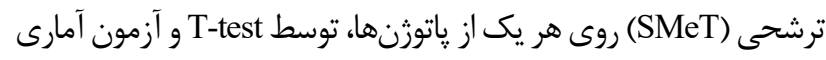

ا قطره (•D ميكروليتر) از سوسيانسيون تهيهشده از هر اندوفيت

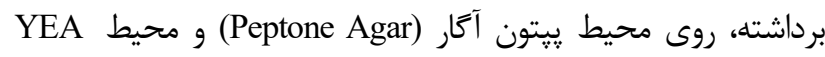
قرار داده و بدون (Merck, 64271, Germany) (Yeast Extract Agar) اينكه يخش شوند درون انكوباتور با دماى VY درجه سلسيوس به مدت

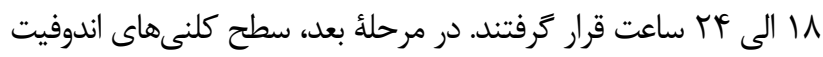

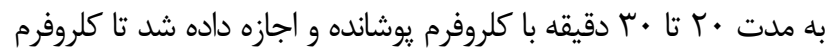

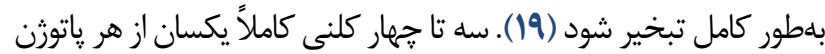
(C. albicans g E.coli ATCC 25922 ،S. aureus ATCC 25923) بهور جداكانه در محيط TSB (Tryptic Soy Broth) كشت داده شدند

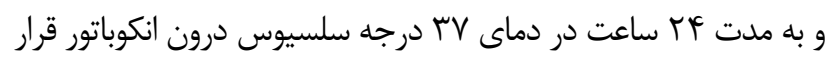

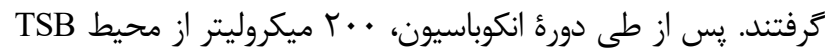

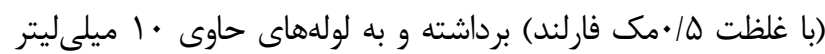

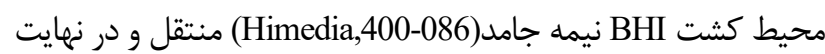
مخلوط شدند. محتويات هر لوله بلافاصله به سطح محيطهاى YEA و

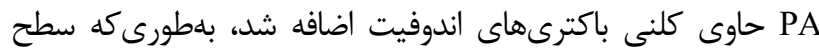

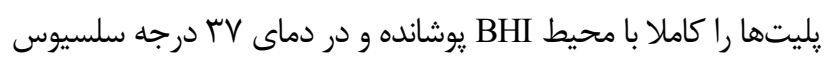

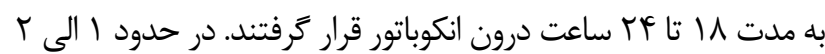
كلنى خالص از قارجترايكوفايتون منتاكروفايتس (T.mentagrophytes) توسط آنس سوزنى در شرايط استريل برداشته و با فاصله 1 cm از

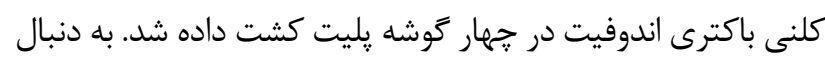
آن، قطر ناحيه مهار رشد ميكروار كانيسمهاى بيمارىزا كه در اطراف

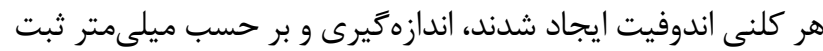

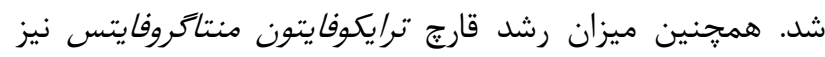

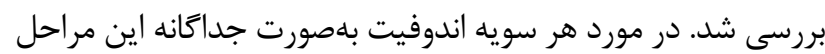
انجام يذيرفت. قبل از انجام مراحل فوق، براى يافتن خواص ضد ضد

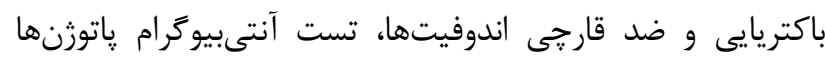

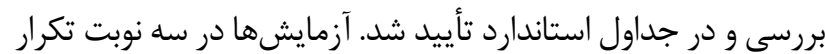

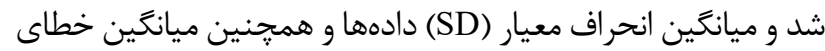
استاندارد (SEM) محاسبه و ثبت شدند (19).

\section{بررسى خواص ضد باكتريايى و ضد قارجى متابوليتهاى ترشحى باكترىهاى اندوفيت (SMeT)} سه الى جهار كلنى از هر باكترى اندوفيت به طور جداكانه LB (Luria Bertani Broth) (Merck, 110285, درمحيط كشت التهري كشت داده و به مدت ل Germany) E. ،. aureus سلسيوس انكوبه شدند. سويههاى استاندارد از جمله C. albicans و در محيط LB coli

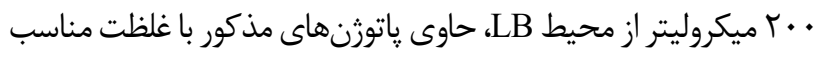




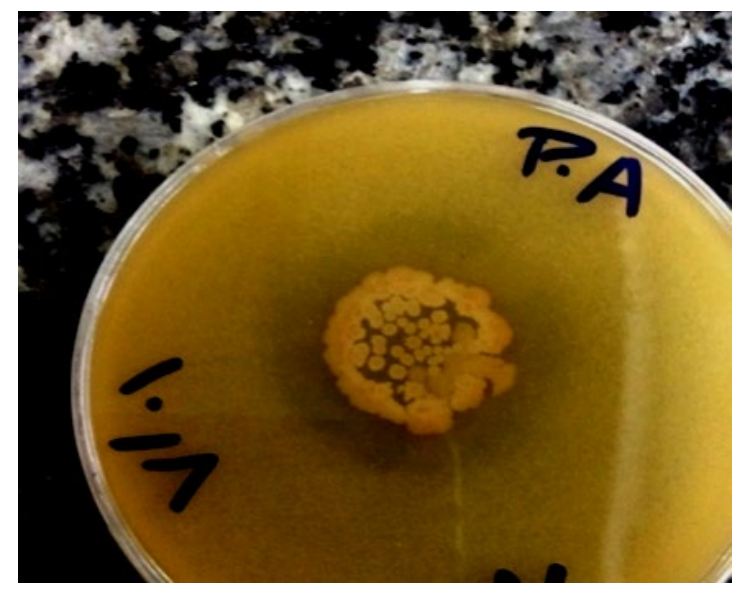

شكل ا. ايجاد هاله عدم رشد باكترى S. aureus (ATCC: 25923 توسط

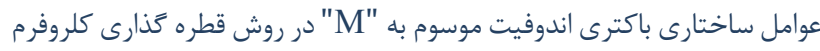
در گياه بنسرخ ساخدان

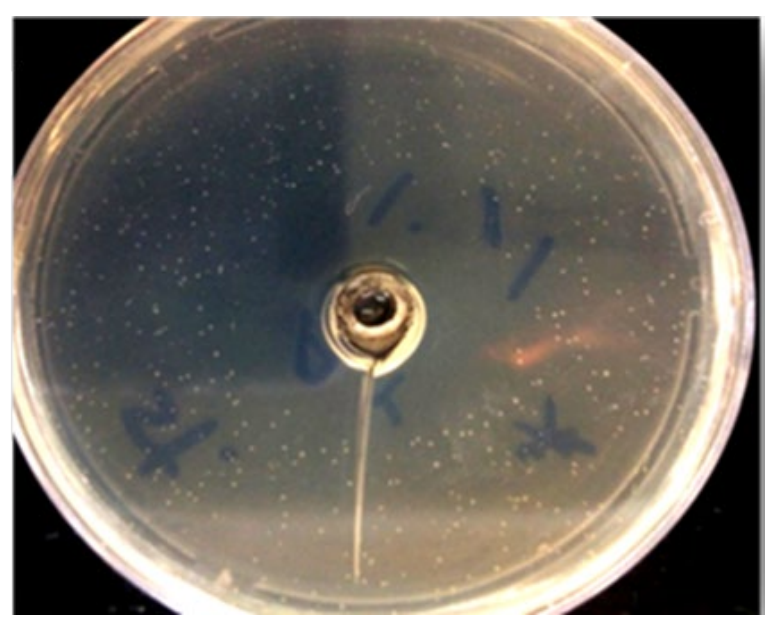

شكل r. تأثير متابوليتهاى ترشحى اندوفيت "S. aureus بر باكترىهاى و خواص ضد باكتريايى A.jesdianum

\section{E.coli (ATCC: 25922) عليه A. jesdianum اثر ضد باكتريايى}

A. Aيج يك از 11 اندوفيت باكتريايى جداشده از

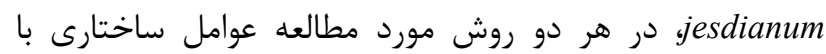
E. coli كلروفرم و ارزيابى اثر ترشحى متابوليتها بر باكترى

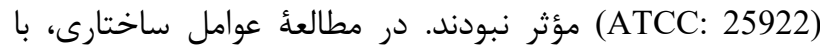

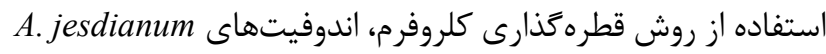
عليه E. coli بى اثر بودند (جدول ().

هالأ عدم رشد بسيار ضعيفى در برابر باكترى E. coli

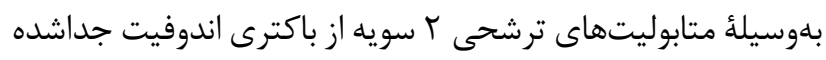
(C1) (C1) ايجاد شد (جدول r).

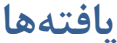
اندوفيت هاى باكتريايى جدا شده

در مجموع | 1 اندوفيت باكتريايى از قسمتهاى مختلف كياه

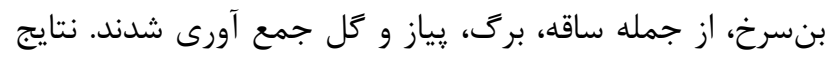
اين مطالعه، اثرات متفاوتى از اندوفيتهاى باكتريايى جدا شدا شده از از

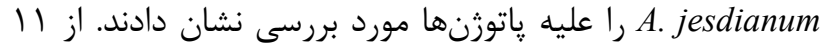

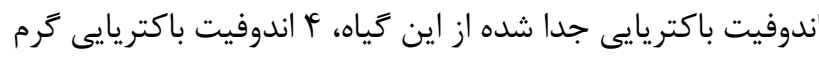

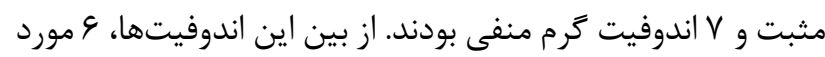
كوكسى، r مورد باسيل و r اندوفيت كوكوباسيل بودند. اندوفيتها

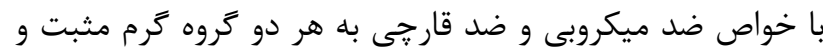

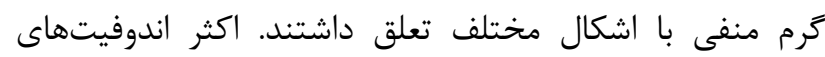
باكتريايى جدا شده از كياه بنسرخ، كوكسى و باسيل بودند. تمام II اندوفيت جدا شده از A. jesdianum در محيطهاى مختلف

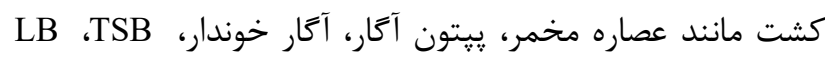

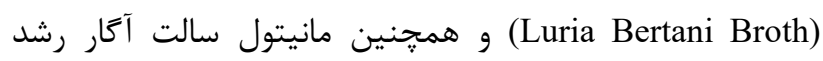
كردند. كلنىهاى اندوفيت باكترى در محيط يֶّتون آكار رشد

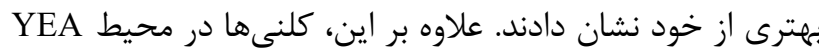
ضعيفتر از محيط PA بودند.

متابوليتهاى ترشحى اندوفيت باكتريايى جداشده از تمام

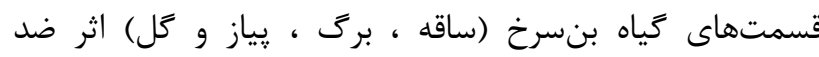

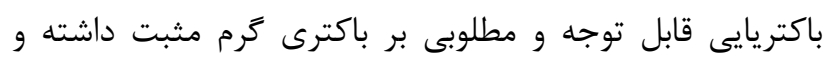

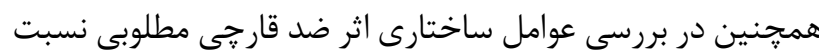

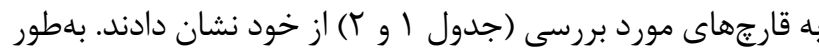

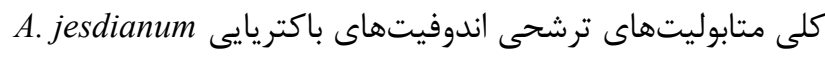

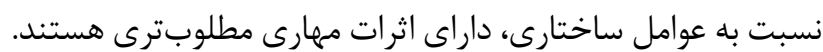

\section{S. aureus اثر ضد باكتريايى كياه بنسرخ عليه پاتوزن}

(ATCC: 25923)

در مطالعئ عوامل ساختارى، از طريق روش قطرهذارى با

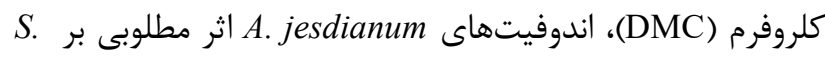
aureus (ATCC: 25923) داشتند (شكل ()).

S. به طور كلى بهترين اثر ضد باكتريايى اندوفيتها بر روى aureus (ATCC: 25923)

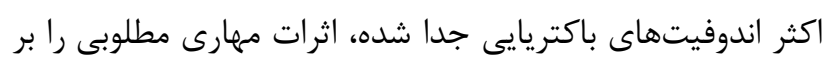
(S. aureus (ATCC:25923) از خود نشان دادند (شكل ؟). 
عليه C. albicans ايجاد كردند. در ساير اندوفيتهاى باكتريايى،

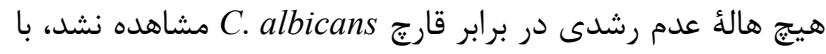

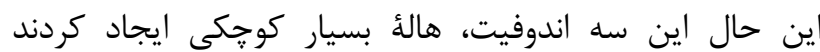

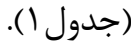

\section{C. albicans اثر ضد قارجى كَياه بنسرخ عليه پِاتوزن} در مطالعه عوامل ساختارى از طريق روش قطرهذارى

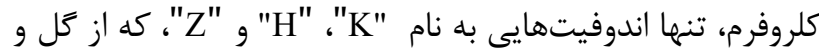
بيازهاى A. jesdianum جدا شدند، هالأ عدم رشد بسيار ضعيفى

جدول ا. ميانكَين قطر (SD هاله عدم رشد باكترىهاى E. coli \& S. aureus و قارج C. albicans بر حسب ميلىمتر بر اساس عوامل ساختارى اندوفيت باكتريايى در A. jesdianum با استفاده از روش قطرهذارى كلنى باكترى با استفاده از كلروفرم

\begin{tabular}{|c|c|c|c|c|c|}
\hline C. albicans (SD) & S. aureus (SD) & E. coli (SD) & اجزاى كياه & مورفولوثى & اندوفيتها \\
\hline$F(r)$ & $r F / Q(1 / Q) *$ & $\cdot(\cdot)$ & يِياز & Bacilli G - & $\mathrm{k}$ \\
\hline$\cdot(\bullet)$ & $r \varphi / \Delta(\Gamma / \Delta)$ & $\cdot(\cdot)$ & برى & Cocci G - & M \\
\hline$\cdot(\bullet)$ & $1 N / \Delta(\Gamma / \Delta)$ & $\cdot(\cdot)$ & برى & Cocco Bacillus G+ & $\mathrm{F}$ \\
\hline$\cdot(\cdot)$ & $\Delta(1)$ & $\cdot(\cdot)$ & برك & Cocci G+ & $c_{1}$ \\
\hline$\cdot(\cdot)$ & $1 / \Delta(1 / \Delta)$ & $\cdot(\cdot)$ & برى & Cocci $\mathrm{G}^{+}$ & $c_{2}$ \\
\hline$\cdot(\cdot)$ & $\cdot(\cdot)$ & $\cdot(\cdot)$ & برى & Cocci $\mathrm{G}^{+}$ & $\mathrm{s}$ \\
\hline$\cdot(\cdot)$ & $\cdot(\cdot)$ & $\cdot(\cdot)$ & برك & Cocco Bacillus G - & w \\
\hline$\cdot(\bullet)$ & $\cdot(\cdot)$ & $\cdot(\cdot)$ & ساقه & Cocci G+ & $\mathrm{B}_{1}$ \\
\hline$\cdot(\bullet)$ & $\mid r / \Delta(\Gamma / \Delta)$ & $\cdot(\cdot)$ & ساقه & Cocci $\mathrm{G}^{+}$ & $\mathrm{B}_{2}$ \\
\hline$r(r)$ & $10(1)$ & $\cdot(\cdot)$ & 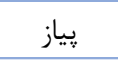 & Bacilli G - & $\mathrm{H}$ \\
\hline$q(1)$ & $r(r)$ & $\cdot(\cdot)$ & كل & Bacilli G - & z \\
\hline
\end{tabular}

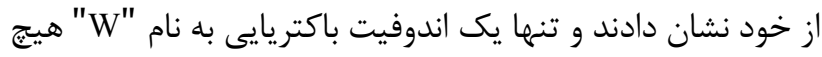
A. متابوليتهاى ترشحى باكترىهاى اندوفيت جداشده از
هالأ عدم رشدى را ايجاد نكرد (جدول r).

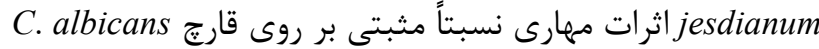

جدول r. ميانكَين قطر (SD) هالdٔ عدم رشد باكترىهاى E. coli \& S. aureus قارج C. albicans ايجادشده تحت تأثير متابوليتهاى ترشحى اندوفيتهاى A. jesdianum باكتريايى

\begin{tabular}{|c|c|c|c|c|c|}
\hline C. albicans(SD) & S. aureus(SD) & E. coli(SD) & اجزاى كياه & 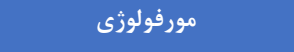 & اندوفيتها \\
\hline $1 \cdot / \Delta(T / \Delta)$ & $r Y(\Upsilon) * *$ & $\cdot(\cdot)$ & يياز & Bacilli G - & $\mathbf{K}$ \\
\hline$\Lambda / \Delta(1 / \Delta)$ & $r Y / \Delta(r / \Delta)$ & $\cdot(\cdot)$ & برى & Cocci G - & м \\
\hline$I r(r)$ & $\cdot(\cdot)$ & $\cdot(\cdot)$ & برى & Cocco Bacillus G+ & F \\
\hline $9(1)$ & $I N / \Delta(\Delta / \Delta)$ & $r(\cdot)$ & برى & Cocci G+ & $\mathrm{C}_{1}$ \\
\hline $\mid r / \Delta(1 / \Delta)$ & $r I(1)$ & $r(\cdot)$ & بركى & Cocci $\mathrm{G}^{+}$ & $\mathrm{C}_{2}$ \\
\hline $11 / \Delta(1 / \Delta)$ & $r V(r)$ & $\cdot(\cdot)$ & بركى & Cocci G+ & $\mathrm{s}$ \\
\hline$\cdot(\cdot)$ & $\mid F / \Delta(\cdot / \Delta)$ & $\cdot(\cdot)$ & 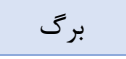 & Cocco Bacillus G - & w \\
\hline $11(1)$ & $r \varphi / \Delta(\Gamma / \Delta)$ & $\cdot(\cdot)$ & ساقه & Cocci $\mathrm{G}^{+}$ & $\mathrm{B}_{1}$ \\
\hline If (1) & $\cdot(\cdot)$ & $\cdot(\cdot)$ & 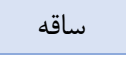 & Cocci G+ & $\mathrm{B}_{2}$ \\
\hline$I T / \Delta(I / \Delta)$ & $r F(r)$ & $\cdot(\cdot)$ & يباز & Bacilli G - & $\mathbf{H}$ \\
\hline $10(Y)$ & $r \Delta / \Delta\left(F^{\epsilon} / \Delta\right)$ & $\cdot(\cdot)$ & كل & Bacilli G - & $\mathbf{z}$ \\
\hline
\end{tabular}

"عدد داخل يرانتز نشان دهنده خطاى استاندارد ميانكين (SEM) است. 
T. برگهاى A. jesdianum جدا شدند، فعاليت ضدقارجى عليه

mentagrophytes اندوفيت باكتريايى جداشده از A.jesdianum هيج تاثيرى در رشد لتدان T. mentagrophytes
اثر ضد قارجى كياه بنسرخ بر قارج Trichophyton mentagrophytes در مطالعه عوامل ساختارى از طريق روش قطرهزذارى

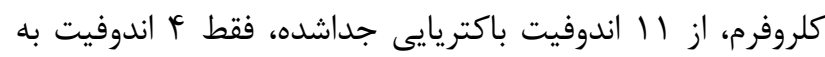

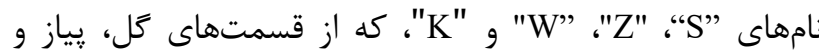

جدول r. خواص ضد قارجى باكترىهاى اندوفيت در برابر رشد Trichophyton mentagrophytes بر اساس فاكتورهاى ساختارى در روش قطرهذارى توسط

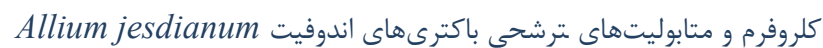

\begin{tabular}{|c|c|c|c|c|}
\hline تأثير عوامل ساختارى اندوفيتهاى & تأثير متابوليتهاى ترشحى & اجزاى كياه & 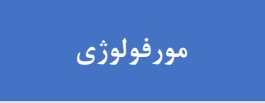 & الدوفيتها \\
\hline منفى & منفى & ساقه & Cocci $\mathrm{G}^{+}$ & $\mathbf{B}_{1}$ \\
\hline منفى & منفى & 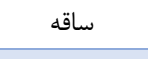 & Cocci $\mathrm{G}^{+}$ & $\mathbf{B}_{2}$ \\
\hline منفى & منفى & برى & Cocci $\mathrm{G}^{+}$ & $\mathrm{C}_{1}$ \\
\hline منفى & منفى & 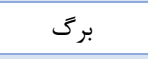 & Cocci $\mathrm{G}^{+}$ & $\mathrm{C}_{2}$ \\
\hline مثبت & منفى & برك & Cocci $\mathrm{G}^{+}$ & $\mathbf{S}$ \\
\hline مثبت & منفى & بركى & Cocco Bacillus G- & $\mathbf{W}$ \\
\hline منفى & منفى & بركى & Cocci $\mathrm{G}^{-}$ & M \\
\hline منفى & منفى & برك & Cocco Bacillus G ${ }^{+}$ & $\mathbf{F}$ \\
\hline منفى & منفى & يبياز & Bacilli G- & $\mathbf{H}$ \\
\hline مثبت & منفى & يباز & Bacilli $\mathrm{G}^{-}$ & $\mathbf{K}$ \\
\hline مثبت & منفى & 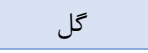 & Bacilli G- & $\mathbf{Z}$ \\
\hline
\end{tabular}

جدول F. قطر هالهٔ عدم رشد ايجادشده در آزمايش آنتىبيوكرام در برابر S.coli S. aureus.

\begin{tabular}{|c|cc|}
\hline E. coli (ATCC:25922) & S. aureus (ATCC: 25923) & Doxycycline \\
\hline- & $1 r$ & Chloramphenicol \\
\hline$r+$ & $1 \uparrow$ & Cefteriaxone \\
\hline$r \cdot$ & $\cdot$ & Nalidixic acid \\
\hline- & $\cdot$ & Furazolidone \\
\hline 19 & 19 & Ampiciline \\
\hline$\cdot$ & $\cdot$ & Lyncomycin \\
\hline- & $r \cdot$ & Streptomycin \\
\hline
\end{tabular}

روش آزمون متابوليت ترشحى (SMeT) وجود دارد. در بررسى اثر

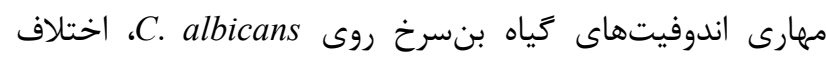

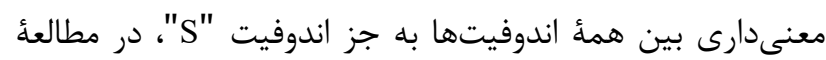

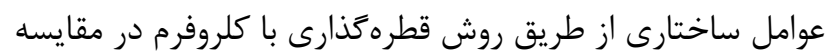
با آزمون متابوليت ترشحى اندوفيتها مشاهده شد. در بررسى ميان

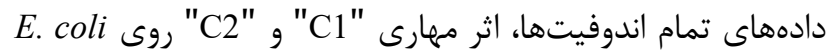
در هر دو روش، اختلاف معنىدارى را نشان دادند. دادههاى بهدستآمده از تأثير اندوفيتهاى مختلف در رور رشد سه سويه بيمارىزا در هر دو روش در جدول ها هارائه شده است.

\section{آزمايش آنتىبيوترام}

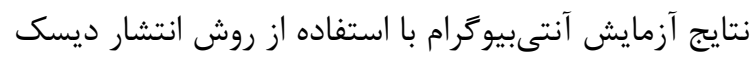
و بررسى قطر هاله عدم رشد ايجاد شده، ارائه شده است (جدول أل).

\section{تجزيه و تحليل آمارى}

S. aureus در بررسى اثر مهارى اندوفيتها روى باكترى اختلاف معنى دارى بين همةٔ اندوفيتها در روش مطالعه عوامل ساختارى بلوسيله قطرهزذارى كلروفرم (DMC) در مقايسه با معند 
جدول ه. مقايسه اثر اندوفيتهاى Allium jesdianum در رشد سه سويه بيمارىزا در هر دو روش مورد مطالعه

\begin{tabular}{|c|c|c|c|c|c|c|c|c|c|}
\hline $\begin{array}{l}\text { Bacterial } \\
\text { Endophyte }\end{array}$ & $\begin{array}{c}\text { S. aureus } \\
\mathrm{DMC}\end{array}$ & $\begin{array}{c}\text { S. aureus } \\
\text { SMeT }\end{array}$ & P-value & $\begin{array}{c}\text { E. coli } \\
\text { DMC }\end{array}$ & $\begin{array}{l}\text { E. coli } \\
\text { SMeT }\end{array}$ & P-value & $\begin{array}{c}\text { C. } \\
\text { albicans } \\
\text { DMC }\end{array}$ & $\begin{array}{l}\text { C. albicans } \\
\text { SMeT }\end{array}$ & P-value \\
\hline B1 & $\cdot / \cdot \pm \cdot \cdot \cdot \cdot$ & $r q / \cdots \pm r / \cdot \varphi$ & $\cdot 1 \cdot 94$ & $\cdot / \cdot \pm \cdot \cdot \cdot \cdot$ & $\cdot / \cdot \pm \cdots / \cdot$ & 1 & $\cdot / \cdot \pm \cdot \cdot \cdot \cdot$ & $\mid r / \cdots \pm r / \cdots$ & $<\cdot 1 \cdots 1$ \\
\hline $\mathrm{B} 2$ & $|r / r r \pm r / \Delta|$ & $\cdot / \cdot \pm \cdots / \cdot$ & $\cdot 1 \cdot \cdot 1$ & $\cdot / \cdot \pm \cdot \cdot / \cdot$ & $\cdot / \cdot \pm \cdots / \cdot$ & 1 & $\cdot / \cdot \pm \cdot \cdot / \cdot$ & $\mid r / G 9 \pm Y / \cdot \Lambda$ & $\cdot 1 \cdot .9$ \\
\hline $\mathrm{F}$ & $\mid N / \cdots \pm r / 9$ & $\cdot / \cdot \pm \cdots / \cdot$ &.$/ \cdot 14$ & $\cdot / \cdot \pm \cdot \cdot / \cdot$ & $\cdot / \cdot \pm \cdot \cdot / \cdot$ & 1 & $\cdot / \cdot \pm \cdot \cdot \cdot \cdot$ & |r/rrEIr/•q & $\cdot 1 \cdot \wedge \wedge$ \\
\hline M & |c|• • • & $r|r r \pm r| \Delta \mid$ & $\cdot / \cdot \cdot V$ & $\cdot / \cdot \pm \cdot \cdot / \cdot$ & $\cdot / \cdot \pm \cdot \cdot / \cdot$ & 1 & $\cdot / \cdot \pm \cdot \cdot / \cdot$ & N/GG $\pm 1 / \Delta T$ & $\cdot 1 \cdot 1$ \\
\hline $\mathrm{H}$ & $|\Delta / \cdot \cdots \pm| / \cdots$ & $r r / G \varphi \pm r / \Delta 1$ & $\cdot 1 \cdot \cdot \Delta$ & $\cdot / \cdot \pm \cdot \cdot / \cdot$ & $\cdot / \cdot \pm \cdot \cdot / \cdot$ & 1 & $r / \cdot V \pm 1 / 9 V$ & $\mid 1 / 99 \pm 1 / \cdot \wedge$ & $\cdot / \cdot r$ \\
\hline $\mathrm{C} 1$ & $F / G \varphi \pm 1 / \Delta F$ & $\mid N / \Gamma r \pm \Delta / \Delta$. & $.1 \cdot 14$ & $\cdot / \cdot \pm \cdot \cdot / \cdot$ & $1 / \cdots \pm \cdot / 94$ & $<\cdot 1 \cdot \cdot 1$ & $\cdot / \cdot \pm \cdot \cdot / \cdot$ & N/TII/Q • & $\cdot 1 \cdot \cdot 1$ \\
\hline $\mathrm{C} 2$ & 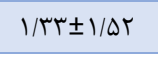 & 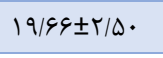 & $<\cdot 1 \cdot \cdot 1$ & $\cdot / \cdot \pm \cdot \cdot / \cdot$ & $1 / \Delta V \pm 1 / r V$ & $<\cdot 1 \cdots 1$ & $\cdot / \cdot \pm \cdot \cdot / \cdot$ & ه•/r & $\cdot 1 \cdot \cdots \wedge$ \\
\hline $\mathrm{K}$ & $r q / \cdot \pm \pm I / V r$ & $r V / \cdots \pm r / \cdots$ & $\cdot / \cdot r \Delta$ & $\cdot / \cdot \pm \cdot \cdot / \cdot$ & $\cdot / \cdot \pm \cdot \cdot / \cdot$ & 1 & $r / \varnothing \varnothing \pm r / \cdot \Lambda$ & $1 \cdot|q 9 \pm Y / \Delta|$ & $\cdot|\cdot r|$ \\
\hline $\mathrm{S}$ & $\cdot / \cdot \pm \cdots / \cdots$ & 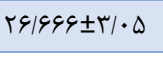 & $<\cdot 1 \cdot \cdot 1$ & $\cdot / \cdot \pm \cdot \cdot / \cdot$ & $\cdot / \cdot \pm \cdot \cdot / \cdot$ & 1 & $\cdot / \cdot \pm \cdot \cdot / \cdot$ & $11 / 99 \pm 1 / 49$ & $<\cdot 1 \cdot \cdot 1$ \\
\hline $\mathrm{Z}$ & $r / \cdots \pm 1 / \wedge r$ & $r F / G G \pm Y / V T$ & $<\cdot 1 \cdot \cdot 1$ & $\cdot / \cdot \pm \cdot \cdot / \cdot$ & $\cdot / \cdot \pm \cdots / \cdot$ & 1 & $9 / \cdots \pm 1 / 41$ & $\mid Q / \cdots \pm r / \cdots$ & $.1 \cdot 1$ \\
\hline
\end{tabular}

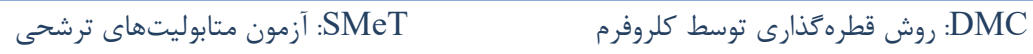

\section{تجزيه و تحليل درون تروهى}

(SMeT)

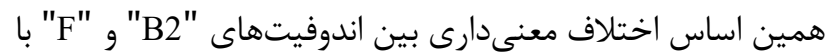
S. aureus ساير اندوفيتها از نظر اثرات مهارى بر روى باكترى

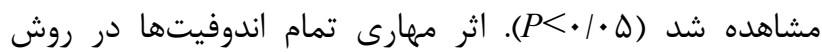
قطرهذارى با كلروفرم و همجنين بررسى متابوليتهاى ترشحى سنى اندوفيتها بر روى S. aureus تجزيه و تحليل شد (شكل س).
در مطالعه عوامل ساختارى از طريق روش قطرهزذارى توسط كلروفرم (DMC)، اختلاف معنى دارى بين اندوفيتهاى "B1"،

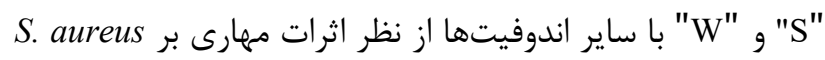
مشاهده شد (ه •|•> اندوفيتها روى باكترى S. aureus در بين اندوفيتهاى ديخر با اين روش تفاوت معنى دارى وجود داشت. باكترى S. aureus بهطور قابل توجهى تفاوت در الگَى رشد را در آزمون متابوليت ترشحى

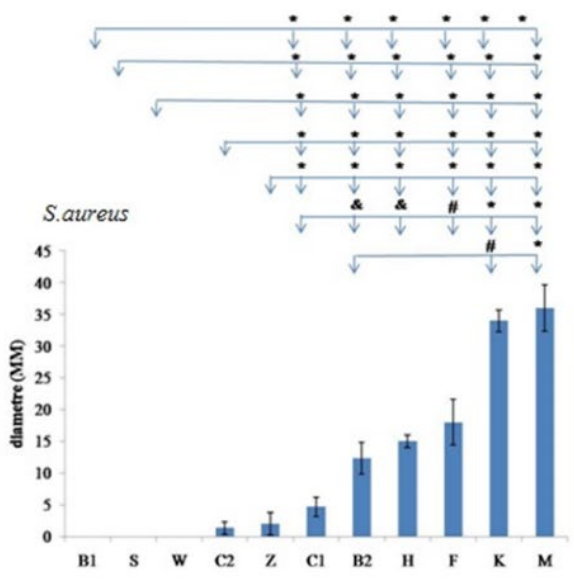

DMC

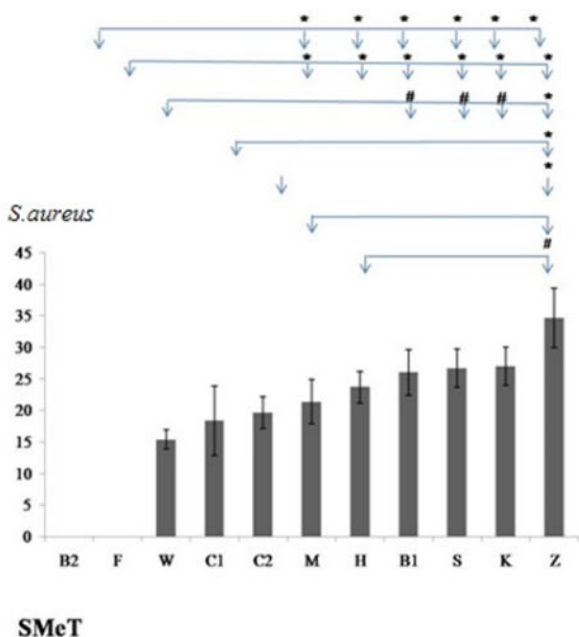

SMeT

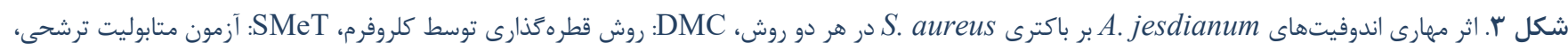

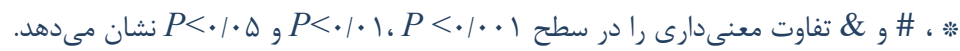

آزمايش در شكل ץ نشان داده شده است. در مطالعه عوامل ساختارى از طريق روش قطرهخذارى توسط كلروفرم، اختلاف
دادههاى بهدست آمده از اثرات مهارى اندوفيتهاى مختلف

حياه بنسرخ روى قارج C. albicans توسط هر دو روش مورد 
در بين اندوفيتهاى باكتريايى مختلف از نظر اثر مهارى در

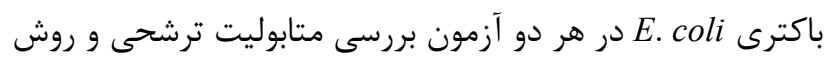

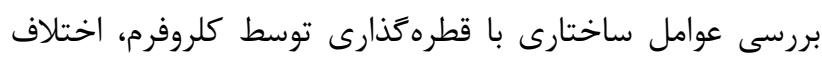

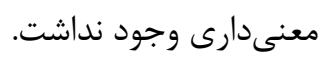

معنى دارى بين اندوفيت "W" با ساير اندوفيتها از نظر اثر مهارى

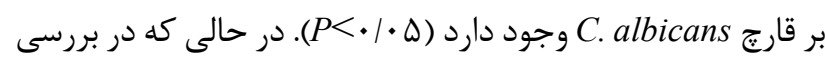

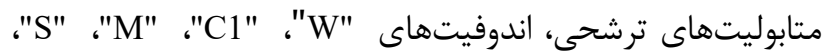

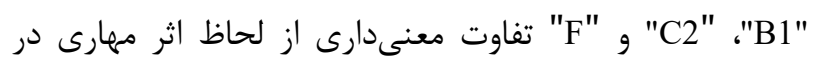

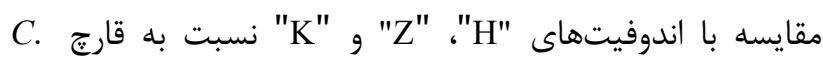
albicans
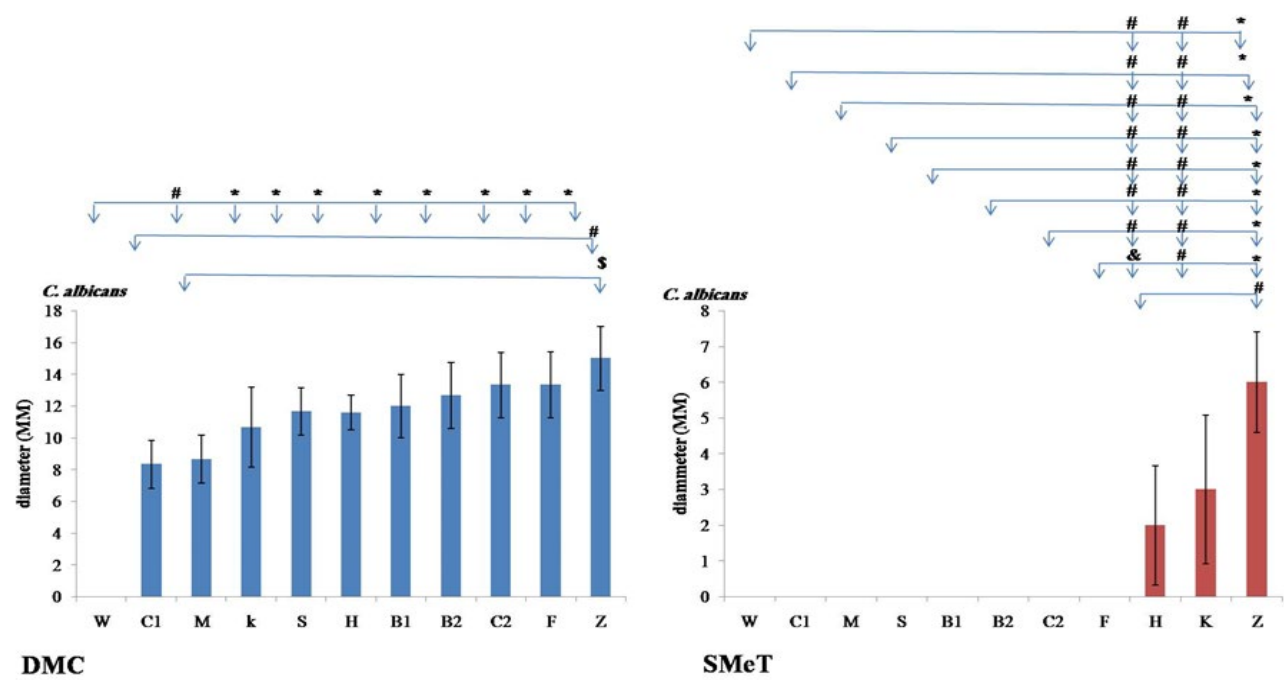

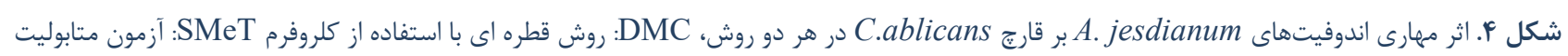

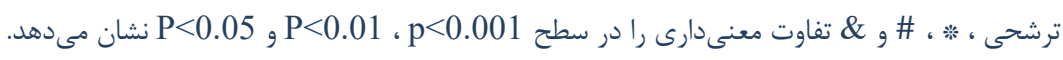

باكتريايى نشان داده شده است (YY). روش ارائهشده در مطالعة

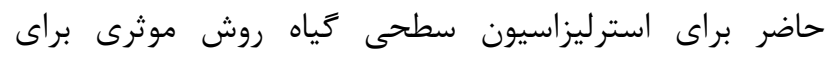

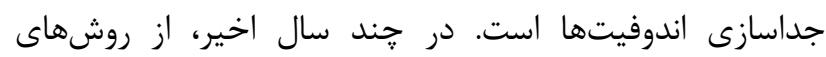

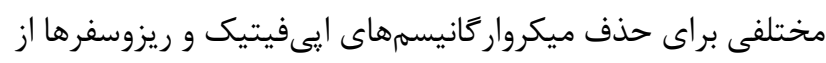

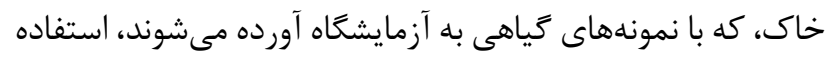

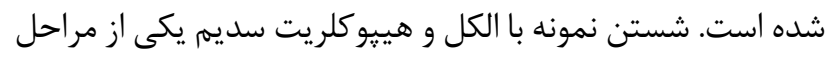

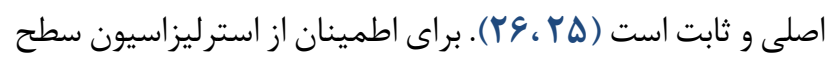

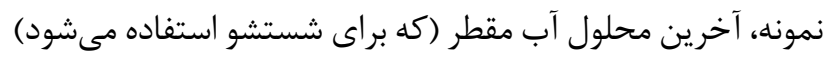

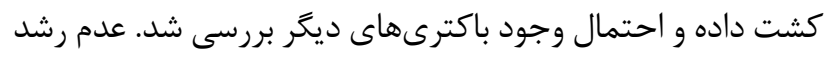

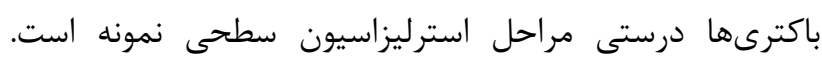

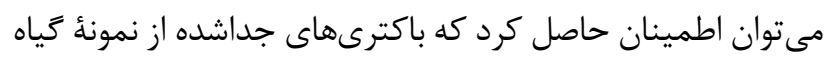

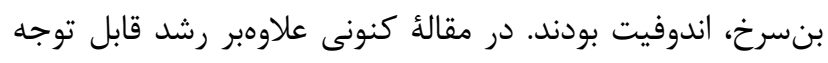

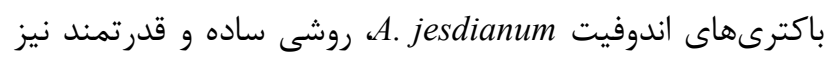

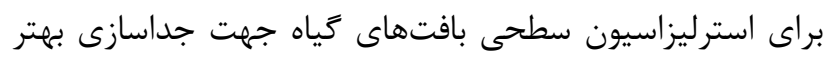

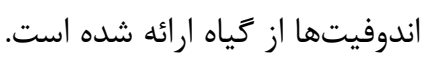

\section{بحث}

از آنجا كه مطالعه حاضر براى بررسى تأثير اندوفيتهاى

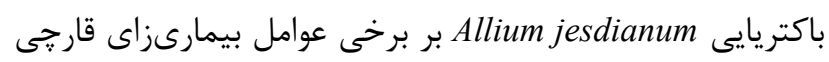

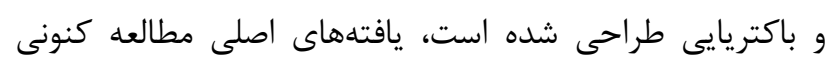

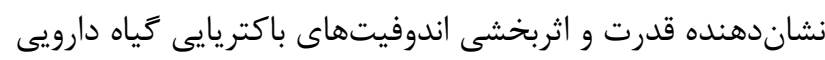

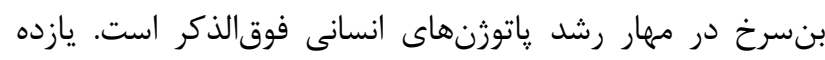

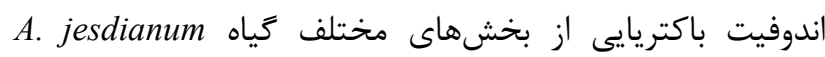

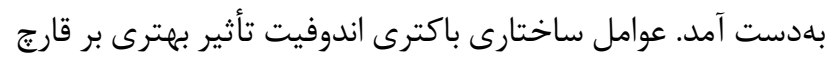
ت T. mentagraphytes

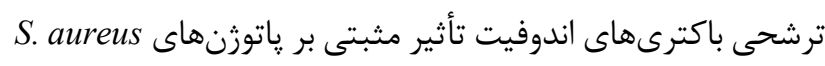

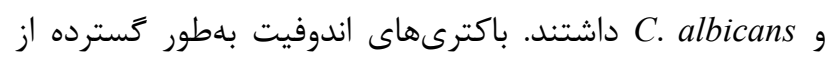

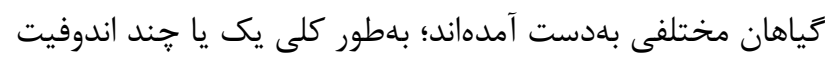

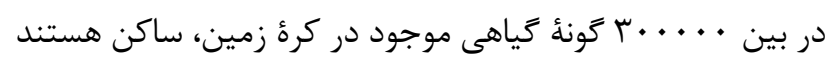

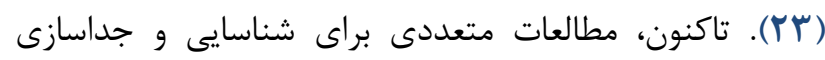

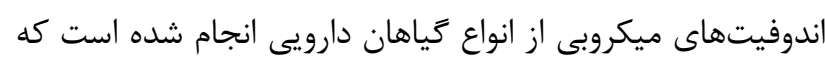

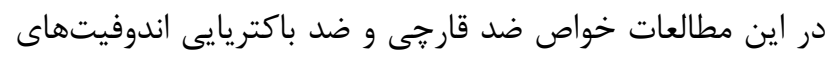


El-Gendy

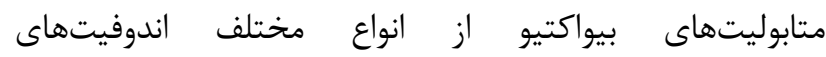

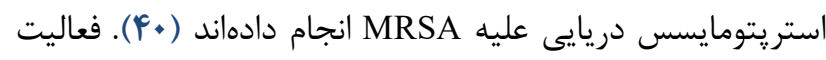
ضد قارجى و اثر ايمنسازى عصار\& A. jesdianum Boiss عليه قارج C. albicans

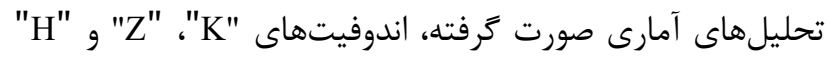

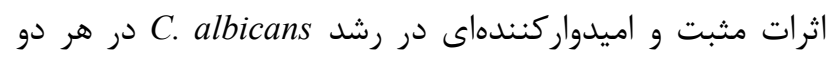

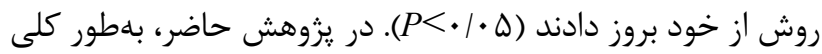
A.

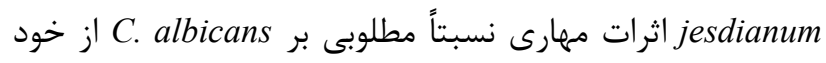
نشان دادند. از ميان يازده اندوفيت جداشده، فقط يك اندوفيت ناتس

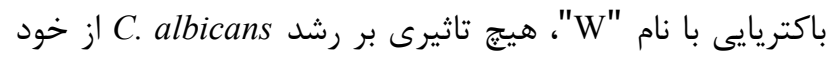

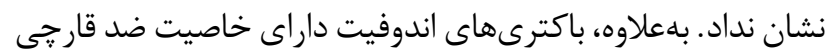

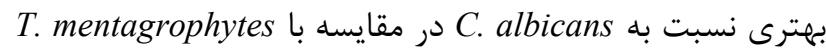
بودند. متابوليتهاى ترشحى تمام اندوفيتهاى باكتريايى جداشده

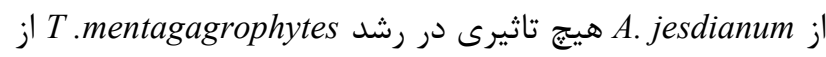

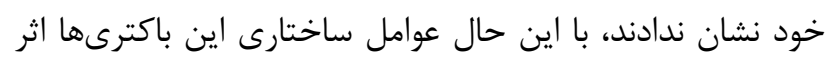

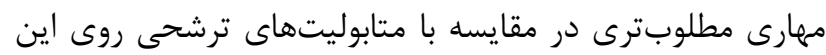

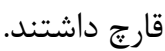

تركيبات ثانويهاى همجون رنحَدانهها، تنظيم كنندههاى رشد

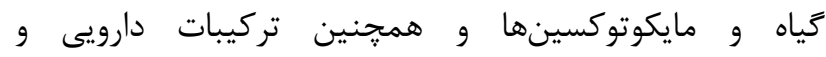
آنتى ياتوزنيك، از جمله متابوليتهاى توليد شده توسط اين ونين

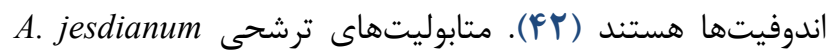
ممكن است حاوى تركيبات ضدباكتريايى، ضدقارج و ساير تركيبات دارويى باشند. بلطور كلى، متابوليتهاى ترشحى اندوفيتهائى

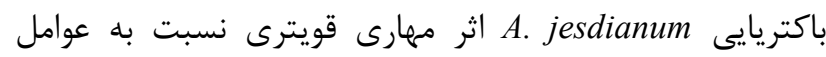

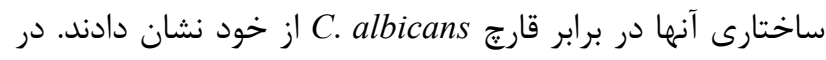

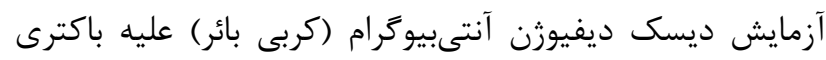
بيشترين قطر هالأ عدم رشد S. aureus (ATCC: 25923) ايجادشده • r ميلىمتر و متعلق به آنتىبيوتيك لينكومايسين بود.

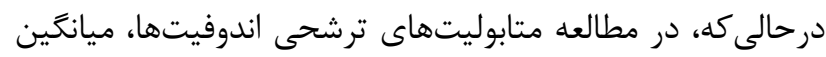

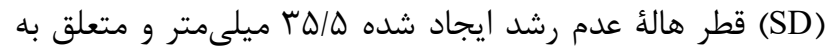

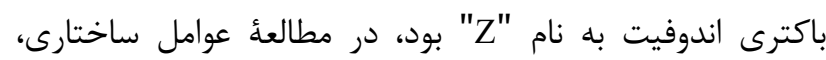

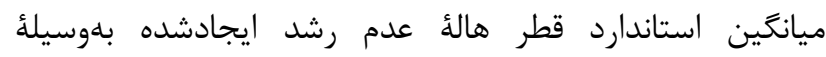

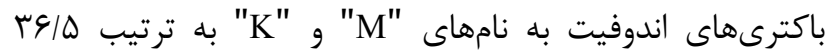

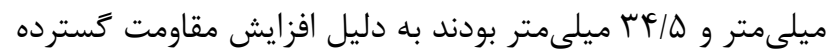

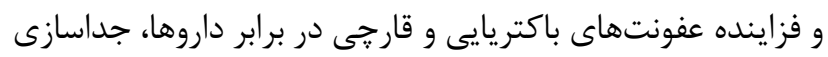

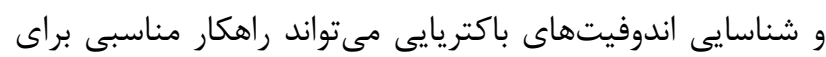

در سالهاى اخير خواص ضد ديابتى و ضد تومورى

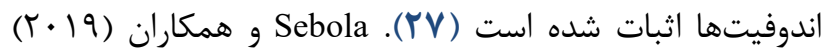
فعاليت ضد باكتريايى عصاره خام اندوفيتهاى باكتريايى را نشان اندان دادند (YN). ييش از اين نيز وجود اندوفيتها در قسمتهاى

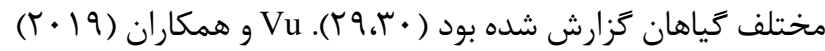

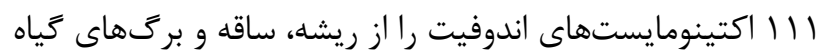
جCinnamomum cassia Presl

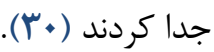
در اين مطالعه، اندوفيتها بهطور عمده از بركها در مقايسه

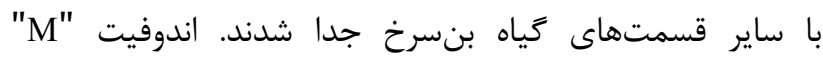

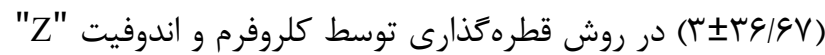

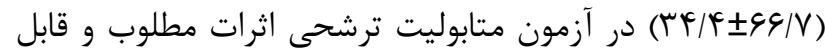
توجهى در مهار S. aureus از خود نشان دادند. ميانكين قطر هالئ عدم رشد ايجادشده در برابر S. aureus بهوسيلة همأ اندوفيتها

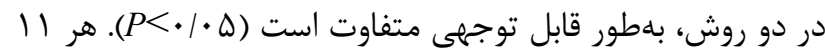
اندوفيت جداشده از Aesdianum يس از

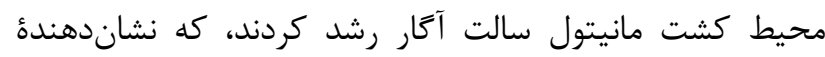
تحمل زياد نمك كلريد سديم در آنها است. اثر بازدارندگى

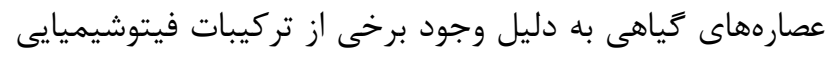

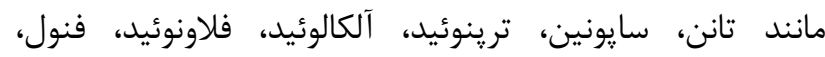
استروئيدها و ساير تركيباتى كه توسط كلروفرم استخراج مىشوند، ايجاد مىشود (اس). تونههاى Allium حاوى تركيبات حياتى همجون كربوهيدراتها، فلاونوئيدها و سايونينها هستند. اين

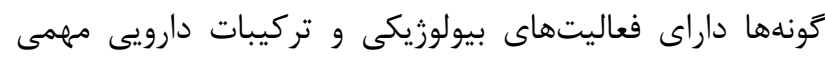

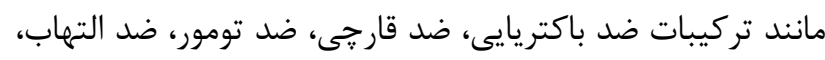

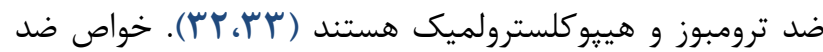
ميكروبى و ضد قارجى اندوفيتها با استخراج اين تركيبات بهوسيلئ

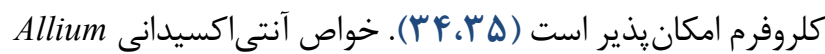

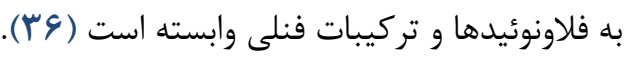
نشان داد كه عصاره اتانولى اثرات ضد Amiri A. ميكروبى قوى jesdianum دارد. خواص ضد ميكروبى روغن و عصارههاى اتانولى ني

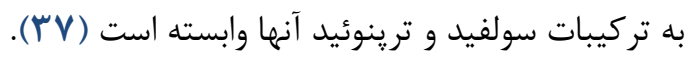
Allium مطالعات نشان دادند كه فراكسيون كلروفرم bakhtiaricum داراى اثر مهار كننده بر سرطان يستان است (؟^). Allium تصور بر اين است كه خواص آنتىاكسيداتيوى كونهان

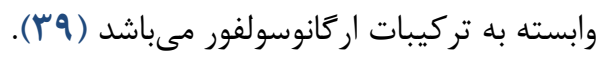


باكترىهاى اندوفيتيك در علوم يزشكى و داروسازى نقش مهمى را ايفا مى كنند. از اندوفيتهاى باكتريايى A. jesdianum و خواص

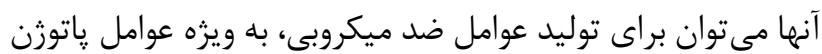
مقاوم در برابر آنتىبيوتيكهاى معمول استفاده كرد. علاوه بر اين، اين تركيبات مىتوانند در علوم داروسازى، كشاورزى و صنايع

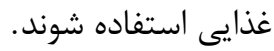
سياسگز ارى اين يزوهش توسط دانشعاه شهركرد پشتيبانى شده است. بدينوسيله از حمايت دانشعاه شهر كرد در انجام اين تحقيق كمال تشكر و قدردانى را داريم grant numbers: 96GRD1M1801 .and 96PRM2M50457)

$$
\text { تعارض در منافع }
$$

نويسندگان هيج گونه تعارضى در منافع گزارش نكردند.

$$
\text { منابع مالى ندارد. }
$$

\section{Referance}

1. Wink M. Modes of action of herbal medicines and plant secondary metabolites. Medicines. 2015;2(3):251-86.

[DOI:10.3390/medicines2030251] [PMCID]

[PMID]

2. Zhang W, Huai Y, Miao Z, Qian A, Wang Y. Systems pharmacology for investigation of the mechanisms of action of traditional Chinese medicine in drug discovery. Front Pharmacol. 2019;10:743. [DOI:10.3389/fphar.2019.00743] [PMID] [PMCID]

3. Mishra VK, Passari AK, Chandra P, Leo VV, Kumar B, Uthandi S, Thankappan S, Gupta VK, Singh BP. Determination and production of antimicrobial compounds by Aspergillusclavatonanicus strain MJ31, an endophytic fungus from Mirabilisjalapa L. using UPLC-ESI-MS/MS and TD-GC-MS analysis. PloS One. 2017; 19; 12(10): 0186234. [DOI:10.1371/journal.pone.0186234] [피] [PMCID]

4. Photolo MM, Mavumengwana V, Sitole L, Tlou MG. Antimicrobial and antioxidant properties of a bacterial endophyte, methylobacteriumradiotolerans MAMP 4754, isolated from combretum erythrophyllum seeds. Inter J Microbiol. 2020; 18; 2020. [DOI:10.1155/2020/9483670] [PMID] [PMCID]

$$
\begin{aligned}
& \text { غلبه بر مقاومت دارويى ايجادشده از سوى عوامل بيمارىزاى } \\
& \text { انسانى باشد (F). (F). دادهاى بهدستآمده از اين مطالعه نشان } \\
& \text { مىدهند كه اندوفيتهاى باكتريايى بهدستآمده از زياه بنسرخ } \\
& \text { اثر مهارى ضد باكتريايى مناسبترى نسبت به باكترىهاى گرم }
\end{aligned}
$$

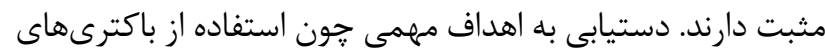

$$
\begin{aligned}
& \text { اندوفيت براى توليد داروهايى با عوارض جانبى كمتر و اثربخشى }
\end{aligned}
$$

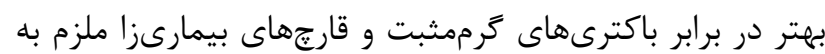

$$
\begin{aligned}
& \text { انجام تحقيقات جامع و گستردهترى مى بـاشد. برى } \\
& \text { و همكاران (1/ Jiang } \\
& \text { بهعنوان اندوفيت بررسى كردند كه در آن مطالعه حداقل اس سويه }
\end{aligned}
$$

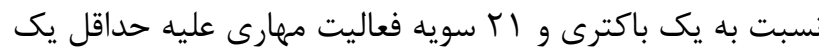

5. Nalini MS, Prakash HS. Diversity and bioprospecting of actinomycete endophytes from the medicinal plants. Lett Appl Microbiol. 2017; 64(4):261-70. [DOI:10.1111/lam.12718] [PMID]

6. Kandel SL, Joubert PM, Doty SL. Bacterial endophyte colonization and distribution within plants. Microorganisms. 2017;5(4):77. [DOI:10.3390/microorganisms5040077] [ [PMCID]

7. Anisha C, Radhakrishnan EK. Metabolite analysis of endophytic fungi from cultivars of Zingiber officinale Rosc. identifies myriad of bioactive compounds including tyrosol. 3Biotech. 2017; 7(2):146.

[DOI:10.1007/s13205-017-0768-8] [PMID] [PMCID]

8. Akinsanya MA, Goh JK, Lim SP, Ting AS. Diversity, antimicrobial and antioxidant activities of culturable bacterial endophyte communities in Aloe vera. FEMS Microbial Lett. 2015;1;362(23). [DOI:10.1093/femsle/fnv184] [PMID]

9. Khalil IA, Troeger C, Blacker BF, Rao PC, Brown A, Atherly DE, et. al. Morbidity and mortality due to shigella and enterotoxigenic Escherichia coli diarrhoea: the Global Burden of Disease Study 19902016. Lancet Infect Dis. 2018; 18(11):1229-40. [DOI:10.1016/S1473-3099(18)30475-4] 
10. Stephens CM, Adams-Sapper S, Sekhon M, Johnson JR, Riley LW. Genomic analysis of factors associated with low prevalence of antibiotic resistance in extraintestinal pathogenic Escherichia coli sequence type 95 strains. Msphere. 2017;26;2(2). [DOI:10.1128/mSphere.00390-16] [미] [PMCID]

11. Ma Y, Lan G, Li C, Cambaza EM, Liu D, Ye X, Chen S, Ding T. Stress tolerance of Staphylococcus aureus with different antibiotic resistance profiles. Microb Pathog. $2019 \quad$ Aug 1;133:103549. [DOI:10.1016/j.micpath.2019.103549] [PMID]

12. Nishimoto, A. T., Sharma, C., \& Rogers, P. D. Molecular and genetic basis of azole antifungal resistance in the opportunistic pathogenic fungus Candida albicans. J Antimicrob Chemother. 2020; 75(2): 257-70.

13. Fisher MC, Hawkins NJ, Sanglard D, Gurr SJ. Worldwide emergence of resistance to antifungal drugs challenges human health and food security. Science. 2018; 18;360 (6390):739-42. [DOI:10.1126/science.aap7999] [PMID]

14. Borek C. Antioxidant health effects of aged garlic extract. J Nutr. 2001;131(3):1010S-5S. [DOI:10.1093/jn/131.3.1010S] [PMID]

15. Choudhary PR, Jani RD, Sharma MS. Effect of raw crushed garlic (Allium sativum L.) on components of metabolic syndrome. J Diet Suppl. 2018;4;15(4):499506. [DOI:10.1080/19390211.2017.1358233] [PMID]

16. Lorigooini Z, Ayatollahi SA, Amidi S, Kobarfard F. Evaluation of anti-platelet aggregation effect of some Allium species. Iran J Pharm Res. 2015;14(4):1225.

17. Pirbalouti AG. Phytochemical and bioactivity diversity in the extracts from bulbs and leaves of different populations of Alliumjesdianum, a valuable underutilized vegetable. Acta Sci Pol Hortorum Cultus. 2019;1;18(2):115-22. [DOI:10.24326/asphc.2019.2.11]

18. Krishnapura PR, Belur PD. Isolation and screening of endophytes from the rhizomes of some Zingiberaceae plants for L-asparaginase production. Prep Biochem Biotechnol. 2016; 2; 46(3): 281-7. [DOI:10.1080/10826068.2015.1031385] [ $\underline{\text { PMID }] ~}$

19. Ratti RP, Serrano NF, Hokka CO, Sousa CP. Antagonistic properties of some microorganisms isolated from Brazilian tropical savannah plants against Staphylococcus coagulase-positive strain. J Venomous Anim Toxins Incl Trop Dis. 2008; 14(2):294-302. [DOI:10.1590/S167891992008000200007]

20. Cruickshank R, Duguid JP, Marmion BP, Swain RH. Tests for identification of bacteria. Med Microbiol. $1975 ; 2: 170-89$.
21. Quinn PJ, Carter ME, Markey B, Carter GR. Enterobacteriaceae. London: Wolfe Publishing; 1994.

22. Yoshida S, Hiradate S, Tsukamoto T, Hatakeda K, Shirata A. Antimicrobial activity of culture filtrate of Bacillusamyloliquefaciens RC-2 isolated from mulberry leaves. Phytopathology. 2001;91(2):181-7. [DOI:10.1094/PHYTO.2001.91.2.181] [PMID]

23. Ryan RP, Germaine K, Franks A, Ryan DJ, Dowling DN. Bacterial endophytes: recent developments and applications. FEMS Microbiol Lett. 2008; 1;278(1):1-9. [DOI:10.1111/j.15746968.2007.00918.x ] [PMID]

24. Hassan SE. Plant growth-promoting activities for bacterial and fungal endophytes isolated from medicinal plant of Teucriumpolium L. J Adv Res. 2017;1;8(6):687-95.

[DOI:10.1016/i.jare.2017.09.001] [PMID] [PMCID]

25. Waheeda K, Shyam KV. Formulation of novel surface sterilization method and culture media for the isolation of endophytic actinomycetes from medicinal plants and its antibacterial activity. J Plant Pathol Microbiol. 2017;1;8(399):2.

26. Zhao H, Yang A, Zhang N, Li S, Yuan T, Ding N, Zhang S, Bao S, Wang C, Zhang Y, Wang X. Insecticidal Endostemonines A-J Produced by Endophytic Streptomyces from Stemonasessilifolia. J Agric Food Chem. 2020; 29; 68(6): 1588-95. [DOI:10.1021/acs.jafc.9b06755] [PMID]

27. Rahman L, Shinwari ZK, Iqrar I, Rahman L, Tanveer F. An assessment on the role of endophytic microbes in the therapeutic potential of Fagonia indica. Ann Clin Microbiol Antimicrob. 2017;1;16(1):53. [DOI:10.1186/s12941-017-0228-7] [ㅁID] [PMCID]

28. Sebola TE, Uche Okereafor NC, Tapfuma KI, Mekuto L, Green E, Mavumengwana V. Evaluating antibacterial and anticancer activity of crude extracts of bacterial endophytes from Crinummacowanii Baker bulbs. MicrobiologyOpen. 2019; 8(12):914. [DOI:10.1002/mbo3.914] [PMID] [PMCID]

29. Taufiq MM, Darah I. Antibacterial activity of an endophytic fungus Lasiodiplodia pseudotheobromae IBRL OS-64 residing in leaves of a medicinal herb, Ocimum sanctum Linn. J Appl Biol Biotechnol. 2019;

7(02):35-41. [DOI:10.7324/JABB.2019.70207]

30. Vu, T.H.N., Nguyen, Q.H., Dinh, T.M.L., Quach, N.T., Khieu, T.N., Hoang, H., Son, C.K., Vu, T.T., Chu, H.H., Lee, J. and Kang, H. Endophytic actinomycetes associated with Cinnamomum cassia Presl in HoaBinh province, Vietnam: Distribution, antimicrobial activity and, genetic features. J Gen Appl Microbiol. 2019;13;66(1):24-31. [DOI:10.2323/jgam.2019.04.004] [PMID] 
31. Umaru IJ, Badruddin FA, Assim ZB, Umaru HA. Antibacterial and cytotoxic actions of chloroform crude extract of Leptadeniahastata (pers) Decnee. Clin Med Biochem. 2018;4:1-4. [DOI:10.4172/24712663.1000139]

32. Asemani Y, Zamani N, Bayat M, Amirghofran Z. Allium vegetables for possible future of cancer treatment. Phytother Res. 2019;33(12):3019-39. [DOI:10.1002/ptr.6490] [PMID]

33. Matsuura H. Saponins in garlic as modifiers of the risk of cardiovascular disease. J Nutr. 2001; 131(3): 1000S-5S. [DOI:10.1093/jn/131.3.1000S] [PMID]

34. Lotfalian S, Ebrahimi A, Mahzoonieh MR. Antimicrobial Activity of Isolated Bacterial Endophytes from CichoriumintybusL, Pelargoniumhortorum, and Portulacaoleracea Against Human Nosocomial Bacterial Pathogens. Jundishapur J Nat Pharm Prod. 2016;12(1). [DOI:10.17795/jjnpp-32852]

35. Rabbee MF, Ali M, Baek KH. Endophyte Bacillus velezensis isolated from Citrus spp. Controls streptomycin-resistant Xanthomonas citri subsp. citri that causes citrus bacterial canker. Agronomy. 2019 Aug;9(8):470. [DOI:10.3390/agronomy9080470]

36. Singh BN, Singh BR, Singh RL, Prakash D, Singh DP, Sarma BK, Upadhyay G, Singh HB. Polyphenolics from various extracts/fractions of red onion (Alliumcepa) peel with potent antioxidant and antimutagenic activities. Food Chem Toxicol. 2009;1;47(6):1161-7. [DOI:10.1016/i.fct.2009.02.004] [PMID]

37. Amiri H. Chemical composition and antibacterial activity of the essential oil of Allium jesdianum Boiss. \& Buhse from Iran. J Med Plants. 2007; 6(1): $39-44$.

38. Vafaee K, Dehghani S, Tahmasvand R, Abadi FS, Irian S, Salimi M. Potent antitumor property of Alliumbakhtiaricum extracts. BMC Complement Altern Med. 2019;19(1):116. [DOI:10.1186/s12906019-2522-8] [PMID] [PMCID]

39. Chiu CK, Chen TY, Lin JH, Wang CY, Wang BS. Protective effects of five allium derived organosulfur compounds against mutation and oxidation. Food chem. 2016;15;197:829-35. [DOI:10.1016/j.foodchem.2015.11.064] [PMID]

40. El-Gendy MM, Mohamed ZK, Hekal NZ, Ali FM, Yousef AE. Production of bioactive metabolites from different marine endophytic Streptomyces species and testing them against methicillin-resistant Staphylococcus aureus (MRSA) and cancer cell lines. BioTechnologia. J Biotechnol Comput Biol Bionanotechnol. 2018;99(1).
41. Naeini A, Yaraee R, Shokri H. Antifungal and immunomodulatory AlliumjesdianumBoiss extracts. J Herbmed Pharmacol. 2019;9(1);75-80. [DOI:10.15171/ihp.2020.11]

42. Leylaie S, Zafari D. Antiproliferative and antimicrobial activities of secondary metabolites and phylogenetic study of endophytic Trichoderma species from Vinca plants. Front Microbiol. 2018;11;9:1484. [DOI:10.3389/fmicb.2018.01484] [PMID] [PMCID]

43. Sharma D, Pramanik A, Agrawal PK. Evaluation of bioactive secondary metabolites from endophytic fungus Pestalotiopsis neglecta BAB-5510 isolated from leaves of Cupressus torulosa D. Don. 3 Biotech. 2016 Dec;6(2):1-4. [DOI:10.1007/s13205-016-0518-

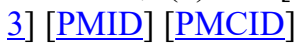

44. Jiang ZK, Tuo L, Huang DL, Osterman IA, Tyurin AP, Liu SW, Lukyanov DA, Sergiev PV, Dontsova OA, Korshun VA, Li FN. Diversity, novelty, and antimicrobial activity of endophytic actinobacteria from mangrove plants in Beilun Estuary National Nature Reserve of Guangxi, China. Front Microbiol. 2018;4;9:868. [DOI:10.3389/fmicb.2018.00868] [PMID] [PMCID]

45. Golinska P, Wypij M, Agarkar G, Rathod D, Dahm H, Rai M. Endophytic actinobacteria of medicinal plants: diversity and bioactivity. Antonie Van Leeuwenhoek. 2015; 108(2): 267-89. [DOI:10.1007/s10482-015-0502-7] [PMCID] 